\title{
YOUTH VIOLENCE IN BOSTON: GUN MARKETS, SERIOUS YOUTH OFFENDERS, AND A USE-REDUCTION STRATEGY*
}

\author{
DAVID M. KENNEDY, ${ }^{* *}$ ANNE M. PIEHL, ${ }^{* * *}$ AND ANTHONY A. BRAGA ${ }^{* * * *}$
}

\section{INTRODUCTION}

Since the mid-1980s, there has been a dramatic increase in youth gun violence. ${ }^{1}$ In most areas, juveniles and many other youth are legally prohibited from purchasing firearms, especially handguns. As a result, many firearms utilized in youth crimes are obtained through active and pervasive illicit gun markets. There is currently very little being done to address these illicit markets, ${ }^{2}$ while at the same time the capacity of police departments to design and implement creative new operational strategies (through "community" and "problem-solving" policing) is increasing. Approaches focusing on illicit firearms markets thus seem a logical and potentially productive strategy. Finally, while enforcement and prevention efforts have so far paid relatively small dividends in reducing youth gun violence, attacking illicit gun markets is an idea which at least has not yet failed. ${ }^{3}$

\section{Copyright $@ 1996$ by Law and Contemporary Problems}

* The research described herein was supported under award \#94-IJ-CX-0056 from the National Institute of Justice, Office of Justice Programs, U.S. Department of Justice. Points of view in this document are those of the authors and do not necessarily represent the official position of the U.S. Department of Justice.

** Senior Researcher, Program in Criminal Justice Policy and Management, John F. Kennedy School of Government, Harvard University.

*** Assistant Professor, John F. Kennedy School of Government, Harvard University.

**** Research Associate, Program in Criminal Justice Policy and Management, John F. Kennedy School of Government, Harvard University.

1. Between 1984 and 1994, juvenile (under 18) homicide victimizations committed with handguns increased by $418 \%$, and juvenile homicide victimizations committed with other guns increased by $125 \%$. During this time period, black males ages 14 through 24 have remained at approximately $1 \%$ of the population, but have increased from 9 to $17 \%$ of homicide victims and from 17 to $30 \%$ of homicide offenders. See JAmES A. FoX, U.S. DeP'T OF JUSTICE, TRENDS IN JUVENILE VIOLENCE: A RePORT TO THE UNITED STATES ATTORNEY GENERAL ON CURRENT AND FUTURE RATES OF JUVENILE OFFENDING (1996). From 1979 through 1989, the firearm homicide rate for persons 15 through 19 years of age increased $61 \%$ from 6.1 to 11.1 deaths per 100,000 ; during the same period, the non-firearm homicide rate decreased $29 \%$, from 3.4 to 2.4 deaths per 100,000 . Rates for black males were higher than for any other race-sex group regardless of degree of urbanization. See Lois A. Fingerhut et al., Firearm and Nonfirearm Homicide Among Persons 15 Through 19 Years of Age, 267 JAMA 3048 (1992).

2. For more on these points, see David M. Kennedy, Can We Keep Guns Away From Kids?, 18 AM. PROSPECT 74, 76 (1994).

3. The idea of attacking illicit firearms markets is not a new one, although it has received little attention relative to other gun control and gun crime reduction approaches and has been little explored 


\section{A. The Boston Gun Project}

Since late 1994, the authors of this article have been working with the Boston Police Department to design a problem-solving intervention addressing youth gun violence in Boston. The authors wished to address the epidemic of youth gun violence and, therefore, focused on "youth" twenty-one years old and under rather than on legal juveniles. At the outset of the project, attention was focused primarily on understanding and addressing the local illicit firearms market. Massachusetts regulates guns more tightly than most states. It is for all practical purposes illegal for those under twenty-one years old to buy handguns in Massachusetts and illegal for those under eighteen years old to buy long guns and ammunition. Those age eighteen to twenty-one can buy long guns and ammunition if issued a state permit to do so, while those twenty-one years old and over can also buy handguns if issued a state permit. Special exemptions exist for those aged eighteen to twenty who require a handgun as a condition of employment in law enforcement and for those under eighteen who obtain state permits to possess long guns for hunting and target-shooting purposes by submitting affidavits from adult legal guardians. ${ }^{4}$ It is thus strictly possible that some guns are being diverted from youth to youth, or bought by youth for their own criminal use under certain circumstances. ${ }^{5}$ The legal special exemptions are rarely utilized, however, particularly for handguns and particularly in the urban areas where youth violence is a problem. More to the point, it is virtually unheard of for guns taken away from youthful offenders or used by youthful offenders in crimes to have been legally purchased by anybody twenty-one years old or under. ${ }^{6}$ With the exception, therefore, of guns obtained legally from adults or "borrowed" from homes in which they are legally possessed, gun acquisition by youthful offenders in the state is very much an illicit-market problem.

operationally, particularly by state and local authorities. See, e.g., STEVEN BRILL, WASHINGTON, DC POLICE Foundation, FIREARM ABUSE: A RESEARCH AND POLICY REPORT 113-43 (1977); ROCHESTER POLICE DEPARTMENT, FINAL REPORT: GUN ABUSE REDUCTION UNIT (1980); Understanding AND PREVENTING ViOlenCe 270-78 (Albert J. Reiss \& Jeffrey A. Roth eds., 1993); Kennedy, supra note 2, at 76; Mark H. Moore, Keeping Handguns From Criminal Offenders, 455 ANNALS AM. ACAD. POL. \& SOC. SCI. 107-09 (1981) [hereinafter Keeping Handguns]; Mark H. Moore, The Bird in Hand: A Feasible Strategy for Gun Control, 2 J. POL'Y ANALYsIS \& MGMT. 188-93 (1983) [hereinafter The Bird in Hand]. For an analysis suggesting that illicit market approaches are unlikely to be effective, see Christopher S. Koper \& Peter Reuter, Suppressing Illegal Gun Markets: Lessons From Drug Enforcement, 59 LAW \& CONTEMP. ProBS. 119 (Winter 1996).

4. MASS. GEN. LAWS ch. 140 (1994).

5. The possibilities are that long guns are being diverted to youth, or being bought for their own criminal use, by members of the following groups: 18-to 21-year-olds who possess normal state permits; individuals age 21 and over who possess normal state permits; youth under 18 who possess a legal special permit; or 18- to 20-year-olds who possess a legal special permit.

6. Interview with Lennie Ladd, Special Agent, Boston Regulatory Office, Bureau of Alcohol, Tobacco, and Firearms (Jan. 1996).

7. See Joseph F. Sheley \& JAMES D. WRight, NAT'L. InST. OF JuSTICE, Gun ACQuisition AND POSSESSION IN SELECTED JUVENILE SAMPLES 6-7 (Dec. 1993) (suggesting that these licit transfer/borrowing routes are actually relatively infrequent among juveniles). 
The joint work of the authors and the police department was intended to proceed by convening an interagency working group, performing original research into Boston's youth violence problem and gun markets, crafting a citywide, interagency problem-solving strategy, implementing that strategy, and evaluating its impact. The authors have played an active role in all aspects of this process, including the following: constituting, convening, and chairing the working group meetings; conducting research; suggesting and exploring intervention possibilities; helping design the larger strategy that emerged from these proceedings; presenting the strategy to policy-making levels in participating agencies; and designing and performing the evaluation. These activities clearly depart from the strict, or at least more heavily, research and evaluation roles usually played by scholars. There are, of course, powerful traditions and norms connected with these more traditional scholarly functions. ${ }^{8}$ The authors, by contrast, regard the Boston Gun Project in part as an experiment in a kind of integrated academic/practitioner partnership perhaps more suitable for policy exercises that blend research, policy design, action, and evaluation. ${ }^{9}$

The research involved has been an unusual combination of quantitative and qualitative analyses. It has revealed the central role of an illicit gun market featuring a flow of relatively new semiautomatic weapons. It has also revealed the central role of a small cadre of highly active gang members as both perpetrators and victims of homicide. Both the gun market and violent gangs seem vulnerable to innovative, but practicable, interventions. A coordinated, interagency strategy has been crafted and is currently being implemented. This article describes the framework for the project, some of its research activities and findings, and the operational strategy that has resulted.

\section{B. Illicit Gun Markets}

To disrupt the illicit markets that provide guns to youth, it would be helpful, first, to understand the markets. Some key issues are the following:

Are what we call illicit gun markets in fact "markets" at all, that is, do they have meaningful pricing regimes, are they organized, are suppliers in business over time, or are they more like bartering and trading systems?

Are the markets that supply youths and adults different?

8. See, e.g., LaMar T. Empey, Field Experimentation in Criminal Justice: Rationale and Design, in HANDBOOK OF CRIMINAL Justice EVAlUaTiOn 143-76 (Malcom Klein \& Katherine Teilmann eds., 1980); Lawrence W. Sherman, Herman Goldstein: Problem-Oriented Policing, 82 J. CRIM. L \& CRIMINOLOGY 690, 693 (1991).

9. See, e.g., David M. Kennedy \& Mark H. Moore, Underwriting the Risky Investment in Community Policing: What Social Science Should be Doing to Evaluate Community Policing, 17 JUST. SYS. J. 271-89 (1995); Kurt Lewin, Group Decision and Social Change, in READINGS IN SOCIAL PSYCHOLOGY 197 (Theodore M. Newcomb et al. eds., 1947); Mark H. Moore, Learming While Doing: Linking Knowledge to Policy in the Development of Community Policing and Violence Prevention in the United States, in INTEGRATING CRIME PREVENTION STRATEGIES: MOTIVATION AND OPPORTUNITIES 12-28 (Per-Olof Wickstrom ed., forthcoming). 
Do different kinds of criminals get their illegal guns in different ways? Do the guns associated with different kinds of crimes and criminals differ in meaningful ways: for example, type, brand, age, caliber, source?

How much of the illicit market is supplied by larger "firms," and how much by smaller or episodic dealers? What constitutes a larger "firm?" How many of these "firms" are primarily in the business of selling illegal guns? How much of the illicit "trade" is buying and selling among strangers? How much is buying and selling among acquaintances? How much is trading and borrowing among acquaintances? How much is trading and borrowing among family members?

To what extent is the illicit trade interstate, and to what extent intrastate? Are those markets supplying adults, youth, and criminals of different kinds different on this dimension?

How much of the illicit market is supplied by theft, and is this proportion getting larger or smaller?

How much of the illicit market is supplied by "scofflaw" federal firearms licensees ("FFLs")?

How much of the illicit market is supplied by fairly direct ("straw purchaser") diversion from the legal primary (FFL) and secondary markets?

How much of the illicit market is supplied by, or operated along channels associated with, the drug trade?

How do gun prices change-if they do change-at different points along the illicit market?

Do any of the above dimensions differ by region or by changes in state and local regulatory regimes?

Unfortunately, our knowledge on these points is primitive. There has been, as noted, very little enforcement attention devoted to illicit gun markets; this is matched by a paucity of research. The research that has been conducted mostly predates the youth gun violence problem, addressing itself instead to how adult felons, who are legally enjoined from buying and owning guns, obtain firearms. ${ }^{10}$ Several basic findings emerged from this literature.

One such finding concerned the structure of the illicit gun market. This market appeared to be primarily composed of many small, multi-faceted operations rather than large, dedicated ones. ${ }^{11}$ The latter did exist and seemed most often organized to move large quantities of weapons from states with few restrictions on gun purchases to states with strict ones. For the most part,

10. See, e.g., JAMES D. WRIGHT \& PETER H. ROSSI, ARMED AND CONSIDERED DANGerous: A SURVEY OF FELONS AND THEIR FIREARMS 39 (1986); JAMES D. WRIGHT ET AL., UNDER THE GUN: WEAPONS, CRIME, AND VIOLENCE IN AMERICA 175-88 (1983); BRILl, supra note 3, at 23-31; Keeping Handguns, supra note 3 , at 102 .

11. See, e.g., ROCHESTER POLICE DEPARTMENT, supra note 3; The Bird in Hand, supra note 3, at 188-93; Keeping Handguns, supra note 3, at 102. 
however, both the multiplicity of sources for illegal weapons-thefts from homes, thefts from gun dealers, improper sales from licensed dealers, private dealers, and diversion of guns obtained through legal purchase-and the ease and convenience of dealing them alongside other contraband eliminated the need for powerful organizations to acquire and distribute black-market guns. ${ }^{12}$ Examinations of illicit gun dealers show the bulk of them to be small and episodic; many of them appeared to be fences selling guns as they would any other illicit commodity, more or less as thieves bring them in. ${ }^{13}$ These studies were unable, however, to establish the contribution to the sum total of illicitly trafficked firearms of, on the one hand, a relatively small number of highvolume traffickers and, on the other hand, a relatively large volume of smallvolume traffickers. This remains a key, and vexing, problem. ${ }^{14}$

Another finding concerned the importance of stolen guns. ${ }^{15}$ Since many stolen firearms are taken from private residences, and since there are estimated to be some 200 million guns in private hands ${ }^{16}$ the pool of available weapons-even if other supplies could be interrupted-is enormous. This stockpile of firearms dwarfs even the considerable annual flow of guns sold new at retail. One study of the firearms used in Boston felonies showed that forty percent of them had been stolen; ${ }^{17}$ a survey of convicted felons showed from forty to seventy percent of felons obtaining their most recent handgun through theft. ${ }^{18}$ Not surprisingly, many felons had little difficulty obtaining firearms. In one survey of incarcerated felons, three-quarters said they would have no trouble arming themselves upon release, "in a matter of a few hours or, at most, a few days," through theft, from friends, or through simple purchase. ${ }^{19}$ Felons identified as "handgun predators"-with more experience of and with greater commitment to gun crimes-were even more certain they could arm themselves, half within a few hours and almost all within a few days. ${ }^{20}$

More recent survey research on juveniles paints a strikingly similar picture. A recent study of juvenile gun ownership by Joseph Sheley and James Wright,

12. See, e.g., Keeping Handguns, supra note 3, at 96-101; The Bird in Hand, supra note 3, at 190-92; Philip J. Cook \& Mark H. Moore, Gun Control, in CRIME 288 (James Q. Wilson \& Joan Petersilia eds., 1995).

13. See Keeping Handguns, supra note 3, at 105.

14. Recent research suggests that much trafficking may be relatively concentrated, at least at the early end of its diversion from the licit market. Half of all Bureau of Alcohol, Tobacco, and Firearms firearms traces are associated with less than half a percent of all federal firearms licensees ("FFLs"). See GlenN L. PierCe ET AL., OfFICE OF ENFORCEMENT, U.S. BUREAU OF AlCOHOL, TOBACCO, AND FIREARMS, THE IDENTIFICATION OF PATTERNS IN FIREARMS TRAFFICKING: IMPLICATIONS FOR FOCUSED ENFORCEMENT TRAFFICKING 14-15 (Dec. 1995).

15. More than 300,000 guns were reported stolen in 1994; most were handguns. See MARIANNE W. ZAWITZ, BUREAU OF JUSTICE STATISTICS, GUNS USED IN CRIMES 6 (1995). It is generally assumed that many, perhaps most, stolen guns are not reported.

16. See Cook \& Moore, supra note 12 , at 268.

17. See Keeping Handguns, supra note 3, at 107.

18. See WRIGHT \& RosSI, supra note 10, at 193-97.

19. Id. at $214,212-13$ tbl. 11 .

20. Id. at 18,214 . 
conducted in four urban areas with high rates of youth gun violence, showed that eighty-six percent of incarcerated juveniles surveyed and thirty percent of male high school students surveyed had owned guns. Seventy percent of inmates and forty-one percent of students said that obtaining guns was "no trouble at all" and street prices for firearms were well below normal retail prices. ${ }^{21}$ Juveniles' guns came from a variety of sources: theft from individuals, houses, and stores; borrowing from friends and family; and purchase from friends, family, drug dealers, and gun stores. ${ }^{22}$ The survey could reveal little about the original source of guns bought on the street, whether, for instance, they were purchased or stolen. The researchers concluded that, given the reported frequency of both theft and transfer among friends and family, it was likely that "theft and burglary were the ultimate source of many of the guns acquired by the juveniles surveyed, but only occasionally the proximate source."23 $^{.23}$

\section{The Decoupling/Fear Story: A Tale of Two Markets}

Running through recent research on youth violence is the powerful role of fear in driving youth gun acquisition. ${ }^{24}$ For some years, it has been a commonplace that the decade-old surge in youth gun violence stemmed from inner-city crack cocaine trafficking. ${ }^{25}$ There is reason to believe, however, that gun

21. See SHELeY \& WRIGHT, supra note 7, at 5-6; JOSEPH F. SHELEY \& JAMES D. WRIGHT, IN THE LINE OF FIRE: YOUTH, GUNS, AND VIOLENCE IN URBAN AMERICA 46 (1995); see also James D. Wright et al., Kids, Guns, and Killing Fields, SoC'Y, Nov./Dec. 1992, at 84, 86-87.

22. Christopher S. Koper and Peter Reuter argue that these features of the gun stockpile, gun flow, and illicit gun trafficking patterns will render illicit trafficking efforts, whether aimed at adults or youth, ineffective because of the difficulty of identifying and preventing gun trafficking transactions and transfers. See Koper \& Reuter, supra note 3. Other conceptions of trafficking prevention suggest opportunities in addition to transaction-focused enforcement. See Mark Kleiman \& Rebecca Young, Factors of Production in Retail Drug Dealing, URB. AfF. REV. 730 (1995); David M. Kennedy, Guns and Youth: Disrupting the Market 2-10 (unpublished paper presented at the 45th Annual Meeting of the American Society of Criminology, Oct. 30, 1993). For accounts of how these frameworks have played out in street drug enforcement, see DAVID M. KENNEDY, NAT'L INSTITUTE OF JUSTICE, Closing the Market: Controlling the Drug TRAde In TAMPA, Florida 4-8 (Program Focus series, April 1993); Mark Kleiman, Crackdowns: the Effects of Intensive Enforcement on Retail Heroin Dealing, in STREeT-LeVEl DRUG ENFORCEMENT: ExAMINING THE Issues 3-34 (Marcia R. Chaiken ed., 1988); Mark Kleiman \& Kerry D. Smith, State and Local Drug Enforcement: In Search of a Strategy, in DRUGS AND CRIME 69-108 (Michael Tonry \& James Q. Wilson eds., 1990); David M. Kennedy, Fighting the Drug Trade in Link Valley, Kennedy School of Government Case Program C16-90-935.0 4-7 (1990).

23. See SHELEY \& WRIGHT, supra note 7 , at 6.

24. SHELEY \& WRIGHT, supra note 7, at 7; CARL S. TAYLOR, Dangerous SOCIETY 23 (1990);

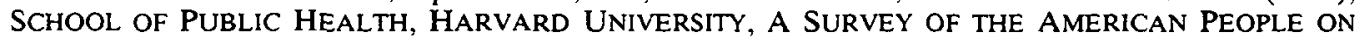
GUNS AS A CHILDREN'S HEALTH ISSUE iv-v (1993) (LH Research, Study 930018); SHELEY \& WRIGHT, supra note 21, at 62-67; Peter Ash et al., Gun Acquisition and Use by Juvenile Offenders, 275 JAMA 1756-57 (1996); Wright et al., supra note 21, at 88.

25. See, e.g., UNDERSTANDING AND PREVENTING VIOLENCE 201-05 (Albert Reiss \& Jeffrey Roth eds., 1995); Alfred Blumstein, Youth Violence, Guns, and the Illicit-Drug Industry, 86 J. CRIM. L. \& CRIMINOLOGY 10 (1995); Jeffrey Fagan \& Ko-lin Chin, Violence as Regulation and Social Control in the Distribution of Crack, in DRUGS AND VIOLENCE, RESEARCH MONOGRAPH OF THE NATIONAL INSTITUTE ON DRUG ABUSE 8 (Mario de la Rosa et al. eds., 1989); Jeffrey Fagan \& Ko-lin Chin, Initiation into Crack and Cocaine: A Tale of Two Epidemics, 16 CONTEMP. DRUG PROBLEMS 579 
acquisition is today not so closely linked to drug trafficking. In particular, it appears that the urban environment has become so threatening even for youth not involved in the drug trade that many are arming themselves (and engaging in other nominally self-protective behavior such as joining gangs) ${ }^{26}$ for selfdefense. We may thus be entering into a second phase of the impact of drugs and drug trafficking on troubled communities. ${ }^{27}$

In the first phase, trafficking and competition among traffickers caused high levels of violence, just as occurred during Prohibition. This violence emerged from business interests and was instrumental in protecting these interests. ${ }^{28} \mathrm{It}$ also, however, profoundly escalated the level of fear and weaponry in affected communities. ${ }^{29}$ Drug traffickers, many of them young and not particularly measured, armed themselves. The streets were the marketplace, so robberies were attempted, and business disputes were often settled, in public. Many traffickers were part-timers, in and out of the business, but once they had guns, they often kept and carried them. The trade was ruled by the same selfregulation that governs all illicit enterprises-those who offend get hurt ${ }^{30}$-but since traffickers were numerous and widely distributed throughout the community, the gangland ethos of violence often came to govern even more ordinary interactions.

This new regime of guns and violence has created a very high level of fear among young men in affected communities. ${ }^{31}$ More than forty percent of the

(1989); Kennedy, supra note 2, at 11.

26. Young men are often motivated to join a neighborhood gang to protect themselves from violence or the threat of violence by rival gangs in proximate neighborhoods. See, e.g., JAMES DIEGO Vigil, BarRio Gangs 129-31 (1988); Felix PADILla, THE GANG AS AN AMERICAN ENTERPRISE 6268 (1992).

27. See Kennedy, supra note 2 , at 11,12 .

28. For more discussion on the systemic violence associated with drug market dynamics, see, for example, BRUCE D. JOHNSON ET AL., TAKING CARE OF BUSINESS: THE ECONOMICS OF CRIME BY HEROIN USERS 174-75 (1985); Paul J. Goldstein, The Drugs-Violence Nexus: A Tripartite Conceptual Framework, 15 J. DRUG IsSUES 493 (1985); Ansley Hamid, The Political Economy of Crack-Related Violence, 17 CONTEMP. DRUG PROBLEMS 31-78 (1990). Terry Williams, through his ethnography in youth cocaine trafficking circles in New York in the late 1980s, regularly found himself in settings he describes as follows: "The apartment is crowded with teenagers, all wearing half-laced sneakers and necklace ropes of gold. Doorbells ring every few minutes, white powder dusts table tops, jagged edge matchbook covers and dollar bills seem to flow from hand to hand. The talk is frenetic, filled with masterful plans and false promises. Everybody has a girl. Everybody has cocaine. Everybody has a

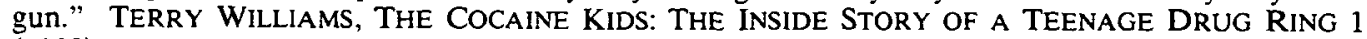
(1989).

29. See, e.g., Kennedy, supra note 2, at 15-17; Blumstein, supra note 25, at 22-32.

30. See Goldstein, supra note 28 , at 497-501; Hamid, supra note 28 , at 31-78.

31. One could describe some neighborhoods as having "tipped," from ones characterized by, and producing, more or less safe "street" conditions to ones characterized by, and producing, fear, aggression, and violence. Other analyses of "tipping" phenomena are Schelling's analysis of white flight, see THOMAS SCHELLING, MICROMOTIVES AND MACROBEHAVIOR 101-02 (1978), Crane's analysis of the effect of high-status workers in a neighborhood on the development of youth, see Jonathan Crane, The Epidemic Theory of Ghettos and Neighborhood Effects on Dropping out and Teenage Childbearing, 96 AM. J. SOCIOLOGY 1226 (1991), Gladwell's discussion of possible explanations for recent dramatic declines in crime in New York City, see Malcolm Gladwell, The Tipping Point, THE NEW YORKER, June 3, 1996, at 32, and Loftin's contagion model to explain growth in gangs and gang violence, see Colin Loftin, Assaultive Violence as Contagious Process, 62 BULL. N. Y. ACAD. MED. 550 (1984). 
high school students surveyed by Sheley and Wright reported having been shot at or threatened with a gun; nearly half knew schoolmates who had actually been fired on. ${ }^{32}$

Not surprisingly, these youths sometimes arm themselves as a means of selfdefense. Sheley, Wright, and M. Dwayne Smith report that for the high-school students they surveyed, a population not heavily involved in drug trafficking, "the desire for protection and the need to arm oneself against enemies were the primary reasons to obtain a gun, easily outpacing all other motivations." 33 Nearly a quarter had done so, and more than a third carried a gun at least occasionally. ${ }^{34}$

In such an environment, the "senseless" shootings that have become an urban commonplace should come as no surprise. These kids are armed, edgy, and believe that they cannot be insulted or walk away from a fight without irretrievably losing face and thereby risking additional victimization. ${ }^{35}$ They are surrounded by violence, leading them to feel that they have few alternatives. They cannot get out of Dodge, nor is anybody making them check their guns at the edge of town. It is more surprising, perhaps, that there is not even more gun violence.

If this picture is correct, that is, if the youth gun problem has become "decoupled" from the drug and gang activity that sparked it some ten years ago, it is an important insight. It implies that measures aimed only at drug trafficking, gang activity, and serious offenders will not be sufficient responses to the problem. It also seems very likely, however, that drug trafficking, serious offenders, and gangs remain a core part of the problem. In Sheley and Wright's 1993 survey, gun possession was associated with drug activity, and the "seriously troublesome" inmates they surveyed were more likely than the students they surveyed to have owned guns, to have carried guns, to have had ready access to guns, to have owned assault-style weapons, to have owned sawed-off shotguns, to have owned semiautomatic pistols, to have owned large numbers of guns, and to have been involved (as both offenders and victims) in violence. Inmates who had trafficked in guns were more involved in gun ownership, gun use, and the commission of other crimes. Those who had gone out of state to buy guns for resale were even more involved. ${ }^{36}$

Conflicts between street gangs have long been noted to fuel much of the youth violence in major cities. ${ }^{37}$ Sheley and Wright found gang membership

32. See SHELEY \& WRIGHT, supra note 7, at 4.

33. See Wright et. al., supra note 21 , at 88.

34. Id.

35. See John Rich \& David Stone, The Experience of Violent Injury for Young African-American Men: The Meaning of Being a "Sucker," 11 J. GEN. INT. MED. 77-82; Elijah Anderson, The Code of the Streets, ATLANTIC MONTHLY, May 1994, at 80-94.

36. See SHELEY \& WRIGHT, supra note 21 , at 64 .

37. See, e.g., CAROLYN R. BLOCK \& RICHARD Block, NAT'L INST. OF JUSTICE, STREet GANG CRIME IN CHICAGO 1-8 (1993); G. DAVID CURRY ET AL., NAT'L INST. OF JUSTICE, GANG CRIME AND LAW ENForCEMENT ReCORDing KeEPING 3-7 (1994); WALTER B. MilleR, ViolenCE by YOUTH 
associated with gun ownership, gun theft, gun sale, gun sharing, and other crimes, and with norms promoting gun ownership and use. ${ }^{38}$ In surveys of arrestees in several cities, Scott Decker and Susan Pennell found gun ownership to have a higher correlation with gang membership than with drug dealing. ${ }^{39}$

If this picture is correct-if a relatively small number of serious, often ganginvolved offenders is one of the main drivers of a larger cycle of fear, gun acquisition, and violence-then gun-market approaches to the youth gun violence problem face a number of serious difficulties. Market-focused interventions are likely to be aimed at reducing access to guns, raising prices, increasing the likelihood that youth will "cash in" the value their weapons represent, and increasing consumers' and dealers' perceptions of vulnerability to enforcement aimed at criminal gun-market activity ${ }^{40}$ In the market driven largely by fear, and perhaps also by style and status issues, these steps may be powerful. In the market driven by criminal behavior, gang membership, and, perhaps, settled aspects of character, they are less likely to be powerful. The serious offender population will tend to be more determined, more criminal, and more likely to need guns for criminal activity and especially drug-market activity, will have greater access to more sources of guns, and, in all likelihood, will be more able to afford the higher prices of firearms. One must fear that these youths will turn to sawed-off long guns if their supplies of handguns are interrupted, a fear supported by Sheley and Wright's research. ${ }^{41}$

These are also, unfortunately, the youth least likely to be influenced by such demand-side interventions as in-school violence reduction curricula, anti-gun violence community campaigns, and the like, particularly after they have already begun to exhibit serious criminal activity. ${ }^{42}$ It would be nice, therefore, if one could invent either demand-side or supply-side interventions likely to have an impact on this population.

Gangs and Youth Gangs as a CRIme Problem in Major American CITIES 30-44 (1975); Malcolm Klein \& Cheryl Maxson, Street Gang Violence, in VIOLENT CRIME AND VIOLENT CRIMINALS 198-203 (Neil A. Weiner et al. eds., 1989).

38. See SHELEY \& WRIGHT, supra note 21, at 95-118.

39. SCOTT DeCKer \& Susan PENNEll, ARREstees and Guns: Monitoring THE Illegal FIREARMS MARKET 1 (1995).

40. See, e.g., Kennedy, supra note 2, at 17-21; Philip J. Cook et al., Regulating Gun Markets, $86 \mathrm{~J}$. CRIM. L. \& CRIMINOLOGY 59-92 (1995); Philip J. Cook \& James A. Leitzel, "Perversity, Futility, Jeopardy": An Economic Analysis of the Attack on Gun Control, 59 LAW \& CONTEMP. PROBS. 91 (Winter 1996).

41. A parallel on all these counts can be drawn with those adult felons Wright and Rossi identified as "handgun felons" in their work in the 1980s on adult gun criminals. See WRIGHT \& Rossi, supra note 10 , at $220-23$.

42. For an overview of the difficulties of intervening in the behavior of chronic youth offenders and some promising approaches, see TED PALMER, THE RE-EMERGENCE OF CORRECTIONAL INTERVENTION 108 (1992); Troy L. Armstrong, Introduction, in INTENSIVE INTERVENTIONS WITH HIGH RISK YOUTHS 1 (Troy L. Armstrong ed., 1991). 


\section{The Boston Gun Project}

It is these core ideas--the key role of illicit markets in supplying youth with guns, the possible role of fear and self-defense in driving gun acquisition, and the problem of a small core of serious youthful offenders - that have framed the Boston Gun Project.

The work of the project's interagency working group, which has met roughly biweekly since early 1995, in the production of research and analysis, in the design of the intervention, and in the implementation of the intervention is perhaps unprecedented in Boston for any substantive crime problem and has resulted in a provocative sharing of information, perspective, and institutional capacities. Membership in the working group currently consists of the Boston Police Department, the Bureau of Alcohol, Tobacco, and Firearms ("BATF"); the U.S. Attorney for the Commonwealth of Massachusetts, the Suffolk County District Attorney, the Massachusetts Department of Probation, City of Boston youth outreach workers, the Massachusetts Department of Parole, City of Boston school police, and the authors. ${ }^{43}$ Data have been collected from these and other agencies; members of the working group (and other agency personnel) have shared their views and experiences; and interviews have been conducted with young probationers to learn about youth behavior, their environment, and their acquisition, carrying, and use of weapons.

The result has been new knowledge and new operational ideas, and a strategy based on both that is currently being implemented by working group participants. Also emerging is an understanding of the importance of a small core group of offenders in driving the city's youth violence problem and a new possibility for regulating their behavior through demand-side interventions. ${ }^{44}$

43. Additional assistance has been provided by the following: the Boston School Department; the Massachusetts Department of Youth Services; the Office of the Attorney General for the State of Massachusetts; the Massachusetts Department of Public Health; and others. Members of the working group were as follows: William Johnston, Paul F. Joyce Jr., Gary French, Fred Waggett, Robert Fratalia, and Jim Jordan of the Boston Police Department; Phil Tortorella and Lennie Ladd of the BATF; William Stewart and Richard Skinner of the Department of Probation; Timothy Feeley and Ted Heinrich of the Office of the U.S. Attorney; Hugh Curran, Elizabeth Keeley, and John Burke of the Suffolk County District Attorney's Office; Tracy Litthcut of the Boston Community Centers; Tim Zadai of the Department of Parole; James MacGillivray of the Crime and Justice Foundation/Project Turnaround; and David M. Kennedy, Anne Piehl, and Anthony Braga of the Kennedy School of Government. Additional participation and support has been provided by, especially, Commissioner Paul Evans and Superintendent James Claiborne of the Boston Police Department, Special Agent in Charge Jeff Roehm of the BATF, Deputy Commissioner Ron Corbett of the Department of Probation, Research Director Scott Taberner of the Department of Youth Services, U.S. Attorney Donald Stern, Suffolk County District Attorney Ralph Martin, Catherine Barber and the staff of the Weapon Injury Surveillance Project at the Department of Public Health, and Ken Caldwell of the Boston School Department.

44. This traditional supply/demand framework is useful up to a point, but ultimately, it is not as particular as one might wish. For analyses of illicit markets using more differentiated frameworks, see Kleiman \& Young, supra note 22, at 731-46; David M. Kennedy, Guns and Youth: Disrupting the Market 1-20 (Oct. 1993) (unpublished manuscript, on file with author). 
These demand-side findings appear to be, if anything, more promising than the supply-side possibilities on which the project originally intended to focus. We begin, therefore, with the demand side. We will then treat our supply-side findings and the operational ideas that flow from them. Finally, we will present a coordinated strategy that links both demand- and supply-side interventions.

\section{A. Youth Gun Violence In Boston}

Boston's youth violence problem is, at least in its broad aspects, typical of that facing other cities. Measured as a homicide problem, it is confined almost entirely to the city's poor black neighborhoods, chiefly Roxbury, Dorchester, and Mattapan (Figure 1), ${ }^{45}$ is concentrated among fifteen to twenty-one year old black males (Figure 2 and Table 1), is largely a firearm problem (seventytwo percent of all homicide victims twenty-one years old and under between 1990 and 1994 were killed with firearms), and generally represents around a third of the city's total homicides, with a decline to around a quarter in 1994 (Figure 3).

Analysis of youth emergency room visits for non-fatal gunshot and sharp instrument wounds showed that injuries are both more numerous in the neighborhoods affected by high levels of gun homicide and exhibit a different pattern. Outside the affected neighborhoods, gunshot woundings are greatly outnumbered by sharp instrument woundings. For instance, in South Boston the count of gunshot injuries to sharp instrument injuries was 2:14 for 1992 to 1994. Inside the affected neighborhoods, however, numbers of gunshot woundings draw equal to or even exceed sharp instrument woundings. For instance, in Roxbury, the count of gunshot injuries to sharp instrument injuries for 1992-1994 was 129:118. ${ }^{46}$ This is evidence of both a more severe problem and a different pattern of weapon use, and it is possible evidence of a different dynamic driving weapon use.

Both young residents and practitioners paint a picture that fits with both the "decoupling/fear" and the "serious youth offender" hypotheses. Youth interviewed recently in Boston portray themselves as choosing between living an ordinary life-including having friends and going out at night-with attendant risks of gun violence, or isolating themselves from friends and community to avoid those risks. ${ }^{47}$ Police, probation officers, gang streetworkers, ${ }^{48}$ and youth

45. We would like to thank Charles Ellis of MaconUSA for his generous help in facilitating certain of the mapping tasks in this project. All tables and figures appear in the appendix, which begins on page 184.

46. These figures were drawn from the Massachusetts Department of Public Health's WeaponRelated Injury Surveillance System ("WRISS"). The Roxbury figures sum zip code-based figures for Roxbury, Grove Hall, and Roxbury Crossing. For 1992 to 1994, all zip code areas of Boston with at least one gang (as described infra) had a gunshot to sharp instrument wound count of 337:380; nongang zip code areas a count of 21:117. Special WRISS runs for Boston were provided by the Department of Public Health to the authors and are available upon request.

47. Youth interviewed have been a convenience sample of probationers, and thus undoubtedly have views and experiences biased toward those of at-risk and criminally involved youth. Youth were introduced to the authors by probation officers or, in one case, the director of a day-reporting program 
describe a world in which a relatively small number of very scary kids profoundly affected the nature of community life and the behavior of other kids. Indeed, police gang officers and probation officers said flatly at the outset of the project that they knew essentially all those youth who had killed, or were killed, by gun violence. Probation officers said that it was rare to lose a kid to gun violence who had not previously been on probation, and the dark joke among gang officers was whether it would be ethical to take out life insurance on certain kids. Their experience was that youth tended to cite self-defense to explain their gun acquisition; Boston police gang officers spoke of the recent phenomena of young men "with a gun in one pocket and a scholarship in the other."

Practitioners had a very particular view of what was going on in the city. Some of their convictions can be captured more or less as follows: The gun violence problem was a gang problem, at least insofar as the worst offenders driving a large cycle of fear, gun acquisition, and gun use were gang members; most victims and offenders were gang members, known to authorities, and had been formally court-involved, sometimes but not usually on gun charges; most violence was not about drugs and drug-market issues or about turf but was more "personal;" acts of violence involving members of different gangs often sparked vendetta-like "beefs" that were assumed by both (or several) gangs; most of the youth involved were not "bad" or inherently dangerous, and many were participating because gang membership had become a means of self-protection (albeit with its own serious risks); and only a tenth or so of gang members were consistently dangerous and frightening, and they set the tone of street life both for the other members of their gangs and, to a lesser but significant extent, for the community as a whole.

It is worth noting that while Boston authorities use the word "gang," as we will here, it is in some sense a term of convenience meaning in practice only "self-identified group of kids who act corporately (at least sometimes) and violently (at least sometimes)." What "gang" means in Boston bears little resemblance to what it means in, for instance, Chicago and Los Angeles. ${ }^{50}$ Thus the following findings, as far as we know, apply only to Boston. But the Boston results were quite striking.

and interviewed either individually or in focus groups during late winter 1994/ summer 1995. Statements attributed to youth herein are generalizations drawn by the authors from these interviews.

48. Statements herein attributed to agency personnel emerged during the working group process described infra. This process included not only formal working group meetings but also ride-alongs with police officers, informal one-on-one conversations, and the like. Nearly all of the process giving rise to the basic description of the gun/gang universe in Boston, as related infra, occurred during the late winter, summer, and fall of 1995.

49. We recognize that defining the term "gang" is a very complex issue. See Richard A. Ball \& G. David Curry, The Logic of Definition in Criminology: Purposes and Methods for Defining "Gangs," 33 CRIMINOLOGY 225 (1995).

50. This commonplace finding is critical to the analysis and comprehension of gang and grouprelated youth crime and violence. The character of criminal and disorderly youth gangs and groups varies widely both within and across cities. See CURRY ET AL., supra note 37, at 2. 


\section{B. The Demand Side: Youth, Crime, and Gangs}

1. Victims and Offenders. We began our analysis of these issues by examining two populations: One population of 155 youth twenty-one years old and under who had been killed by guns or knives in the five years from 1990 to $1994,{ }^{51}$ and one of the 125 youth twenty-one years old and under known to have killed, by gun or knife, someone twenty-one years old and under in the same period. We chose twenty-one as a cutoff age somewhat arbitrarily; we were primarily interested in the "youth homicide problem," which is clearly not limited to legal juveniles (in Massachusetts, those under seventeen), but we did not wish to confuse our analysis by extending it too far into age groups associated with more traditional criminal activity. ${ }^{52}$ We focused on gun homicides for obvious reasons. We included knife homicides because we suspected that guns and knives were to some extent substitutable for one another, and because our larger interest was in youth homicide as such..$^{53}$

First, analysis of the 155 victims and of the 125 known offenders indicated a population with a high level of prior criminal involvement. Of the 155 victims, seventy-five percent (117) had been arraigned in Massachusetts courts prior to their killings; nineteen percent (twenty-nine) had been committed to a Massachusetts Department of Youth Services ("DYS") facility or an adult correctional facility; forty-two percent (sixty-five) had been sentenced to probation; and fourteen percent (twenty-two) were on probation when they were killed. The 117 victims with criminal histories had, collectively, been charged with an average of 9.5 offenses per victim: 173 drug offenses; 291 property offenses; 225 armed violent offenses; 132 unarmed violent offenses; seventy-eight firearms offenses; twenty offenses involving other weapons; 196 disorder offenses; and two homicides. Of the 125 known murderers, seventyseven percent (ninety-six) had, before committing their homicides, been arraigned in Massachusetts courts, twenty-six percent (thirty-three) had been committed to a DYS or adult facility, fifty-four percent (sixty-eight) had been sentenced to probation, and twenty-six percent (thirty-three) were on probation when they killed. The ninety-six offenders with criminal histories had, collectively, been charged before committing their homicides with an average of 9.7 offenses per killer: 141 drug offenses; 248 property offenses; 160 armed violent offenses; 151 unarmed violent offenses; 71 firearms offenses; 8 offenses

51. This sample excluded four obviously non-"street" crimes that otherwise fit this profile (one accident, one suicide, and two fetal homicides).

52. Given the conclusion that emerged from our research that we were dealing primarily with a gang-involved population, an age cut-off as high as 24 would probably have been realistic; according to our practitioner partners, at around that age, male gang members in Boston seem to "age out" of gangs or change their pattern of gang behavior toward somewhat calmer money-making activities.

53. As our interest expanded to include gang homicide, it became clear that it would have been appropriate to include homicide by other means as well. However, our larger analysis would probably not have been overly influenced by doing so. This would have involved an additional 26 incidents or $14 \%$ of what would then have been a total of 181 incidents. 
involving other weapons; 146 disorder offenses; and 3 prior homicides. ${ }^{54}$ More than thirty percent of all victims and offenders-and more than forty percent of victims and offenders known to the criminal justice system-had ten or more arraignments $^{55}$ (Table 2).

It is difficult to compare these victim/offender profiles to baseline information on criminal histories for the youth in the three Boston neighborhoods where most of these murders occurred. ${ }^{56}$ We believe criminal involvement for both victims and offenders to be well above the norm. Note, however, that the line of inquiry we are pursuing is not the usual "dangerous offender" approach to identifying criminals at high risk for serious violence. In the dangerous offender approach, the goal is to highlight future violent offenders by finding patterns in their records. Thus, the question of the distinguishability of the criminal careers of violent and nonviolent offenders is crucial. ${ }^{57}$ Our inquiry, however, explores the argument of practitioners in the Boston Gun Project working group that they were already more or less aware of the youth at high risk for violent offenses, and that these youth are high-rate offenders (and probationers and gang members)-nearly the reverse, in fact, of the dangerous offender strategy.

2. Gangs. Next, we estimated the number and size of the city's gangs and mapped their turf, antagonisms, and alliances. ${ }^{58}$ This mapping was performed

54. These arraignment histories were generated by running victims' and offenders' names through the Massachusetts Criminal Offender Record Information System. Thus, any non-Massachusetts offenses would not have been captured. A methodological note on this process, including assignment and coding rules, is available from the authors upon request.

55 . The worst $5 \%$ and worst $10 \%$ of the 125 offenders were responsible for $20 \%$ and $36 \%$ of 1,009 total arraignments, respectively. The worst $5 \%$ and worst $10 \%$ of the 155 victims were responsible for $17 \%$ and $33 \%$ of 1,277 total arraignments, respectively. Both concentration of offending and "skewness" is characteristic of general and offending populations. See MARVIN E. WOLFGANG ET AL., DELINQUENCY IN A BIRTH COHORT 88-105 (1972); PETER GREENWOOD, RAND CORPORATION, SELECTIVE INCAPACITATION 11-26 (1982); Alfred Blumstein, Crime Control Strategies Using Criminal Career Knowledge, in CRIMINAL CAREERS AND CAREER CRIMINALS 31-54 (Alfred Blumstein et al. eds., 1986). There is surprisingly little research on the actual criminal backgrounds of homicide victims and offenders. However, it has long been known that homicides are likely to take place among family, intimates, and friends. See Colin Loftin et al., An Attribute Approach to Relationships Between Offenders and Victims in Homicide, 78 J. CRIM. L. \& CRIMINOLOGY 259 (1987). Homicides are also likely to be part of a pattern of continuing violence (especially, but not exclusively, for domestic homicide). See Angela Browne, Assault and Homicide at Home: When Battered Women Kill, 3 ADVANCES IN APPLIED SOC. PSYCHOL. 57 (1986). Homicide offenders are also likely to commit their murders in the course of long criminal careers. See BUREAU OF JUSTICE STAT., U.S. DEP'T OF JUSTICE, MURDER IN LARGE URBAN COUNTIES 8 (1988). Homicide victims and offenders are even likely to share networks and similar social milieus. See James Garofalo, Reassessing the Lifestyle Model of Criminal Victimization, in POSITIVE CRIMINOLOGY 23-42 (Michael Gottfredson \& Travis Hirschi eds., 1987); J. Lauritsen et al., The Link Between Offending and Victimization Among Adolescents, 29 CRIMINOLOGY 265 (1991).

56. The systems do not permit, for instance, selection of individuals by age, neighborhood of residence, or probation status.

57. See GREENWOOD, supra note 55, at x-xiv; Blumstein, supra note 55, at 109-54.

58. For a complete discussion of the mapping exercise, see David Kennedy et al., The (Un)Known Universe: Mapping Gangs and Gang Violence in Boston, in CRIME MAPPING AND CRIME PREVENTION (David Weisburd \& J. Thomas McEwen eds., forthcoming). 
by the authors using input from the following sources: the Boston Police Department's Youth Violence Strike Force, probation officers, especially officers involved in an innovative Boston-focused community probation program, ${ }^{59}$ and city "streetworkers," gang prevention and mediation specialists attached to the mayor's office. There was considerable agreement among the three groups, with the streetworkers estimating marginally higher gang memberships than the police and probation officers. The researchers did not specify what "gang" meant or what was to count as a gang; however, in practice, the practitioners used the conception mentioned above. Remarks such as "[group in question] isn't a gang anymore, they just sell drugs" were common. As this remark suggests, Boston's gang landscape is dynamic. According to street-level authorities and gang members themselves, gangs change form, appear, and disappear, albeit slowly. ${ }^{60}$

Our gang-mapping exercise focused on the Boston neighborhoods at high risk for youth violence. According to this process, Boston has some sixty-one gangs, with 1,100-1,300 members, in Roxbury, Dorchester, Mattapan, Hyde Park, the South End, and Jamaica Plain. Only a few of these gangs reach the sixty to 100 member range, with membership of less than ten not uncommon (Table 3). Gang membership estimates were not limited to those twenty-one years old and under, but encompassed all those believed to be active gang members. In order to estimate the proportion of Boston youth involved in gangs, we compared the membership estimates to 1990 Boston census data for the youth fourteen to twenty-four years old. Using this method, the 1,100-1,300 youth involved represent only about three percent of the youth in those neighborhoods, and only about one percent of Boston's youth. ${ }^{61}$

Geographically, the gang landscape is highly balkanized (Figure 4). Gang turfs often occupy only a piece of a block and rarely take up more than a few blocks; some gangs claim only a particular (and often small) apartment building and the street immediately around it. ${ }^{62}$ Network constructions of gang conflicts show complicated patterns (Figure 5). Several aspects, however, are particularly

59. This program, called "Nightlite," puts probation officers on patrol, accompanied by police officers, in the evening in Boston's high-risk neighborhoods.

60. Street gangs and gang activity tends to occur in cycles according to seasonal, group dynamic, and epochal variations; these variations have been documented in Boston, New York, Chicago, Los Angeles, Baltimore, and Washington, D.C. See Malcolm W. Klein, Street Gang Cycles, in CRIME 217 (James Q. Wilson \& Joan Petersilia eds., 1995).

61. US Census data for Boston in 1990 show 123,791 youths city-wide in the 14-24 age group $(1,300 / 123,791=0.01)$, and 49,794 in all census neighborhoods (Hyde Park, Jamaica Plain, North Dorchester, Roxbury, South Dorchester, South End) with at least one gang $(1,300 / 49,794=0.026)$. The small proportion of Boston's youth involved in gangs is consistent with estimates of youth participation in gangs from other cities. See Finn-Aage Esbensen \& David Huizinga, Gangs, Drugs, and Delinquency in a Survey of Urban Youth, 31 CRIMINOLOGY 565-87 (1993); IRVING SPERGEL, THE YOUTH GANG PROBLEM: A COMMUNITY APPROACH 30-33 (1995).

62. The sum total geographic area of the 61 gang turf areas is less than $4 \%$ of the City of Boston. About $25 \%$ of selected crimes and calls for police service (youth homicide, weapons offenses, simple and aggravated assault, drug arrests, armed robbery, and "shots fired" calls) occur inside the gang areas. See Kennedy et al., supra note 58. 
noticeable: Certain particularly significant "nodes" (Castlegate, Academy) seem evident, and identifiable, more or less pervasive, but often quiescent rivalries outnumber "live" and active rivalries.

3. Gangs and Homicide Victimization. Finally, the team of police, probation, and streetworkers examined the five-year list of homicide victimizations to see which were connected to this universe of gangs and gang disputes. Some sixty percent of the homicides can, with some confidence, be attributed to the gangs. ${ }^{63}$ This is a conservative estimate, since cases in which the circumstances were unknown or ambiguous were considered not gang-related. ${ }^{64}$ The majority of the homicides identified as gang-related were not about drugs, money, turf, or other issues in which the violence could reasonably be construed as instrumental. ${ }^{65}$ They were usually, as both gang members and street-level city authorities hold, personal and vendetta-like. ${ }^{66}$ (This does not, of course, mean that current vendettas might not have started, at some point, over drugand money-related issues, only that if they did have such a genesis, they had taken on independent life by the time our examination took place.) They were also, for the most part, not "senseless" or random, at least to the participants.

63. These classifications are not based on official information about homicides and do not represent the official position of any agency or any part of any agency.

64. Law enforcement agencies in different cities use different definitions for "gang-related" crime, which affect the amount of gang-related crimes reported. For example, Los Angeles police define crime as "gang-related" when gang members participate, regardless of motive; Chicago police use a more restrictive definition and classify homicides as "gang-related" only if there is a gang motive evident. See Cheryl Maxson \& Malcolm W. Klein, Street Gang Violence: Twice as Great or Half as Great?, in GANGS IN AMERICA 6 (C. Ronald Huff ed., 1990). For our purposes, homicides were considered connected to gangs if (1) the murderer was a gang member and (2) the motivation behind the murder was known or believed to be connected to gang activity, or if (1) the victim was a gang member and (2) the motivation behind the murder was known or believed to be connected to gang activity. Thus, the killing of a gang member by another gang member in a dispute over contested turf would be considered gang-related; the killing of a non-gang bystander during the same dispute would be considered gang-related; the killing of a gang member by a non-gang member during a robbery attempt would not be considered gang-related. Most of the homicides about which police, probation officers, and streetworkers were knowledgeable fell reasonably clearly into these categories. Those homicides about which they were not knowledgeable were considered not gang-related. The assignment process also suggested that the original pool of 155 homicides could arguably be reduced, since some of the killings represented were not of the "street" character the gun project is designed to address; these include, for instance, domestic homicides committed by non-youth.

65. Most research on gang violence has found that violent behavior tends to be expressive rather than instrumental. See Scott Decker, Collective and Normative Features of Gang Violence, 13 JUST. Q. 243 (1996). However, Sanchez-Jankowski's ten-year observational study of gangs in Los Angeles, New York City, and Boston argued that gangs are purposive organizations and much gang violence is instrumental in nature. See MARTIN SANCHEZ JANKOWSKI, ISLANDS IN THE STREET 176-80 (1991).

66. Research has found most gang violence to be retaliatory in nature. See, e.g., BLOCK \& BLOCK, supra note 37, at 8; SCOTT DECKER \& BARRICK VAN WINKLE, LIFE IN THE GANG: FAMILY, FRIENDS, AND VIOLENCE 186 (1996); Klein \& Maxson, supra note 37, at 9. Colin Loftin argues that a contagion model can be used to explain growth in gangs and gang violence. Retaliatory violent acts and threats of violence support the spreading and growth of gangs within and across neighborhoods. Three conditions must be present for contagion to occur: a spatial concentration of assaultive violence, a reciprocal nature to assaultive violence, and an escalation in assaultive violence. See Loftin, supra note 31 , at $550-55$. 
They had a history, however absurd to observers, and the episode was part of a larger story. ${ }^{67}$

4. The Larger Picture. A clear picture thus emerges. Most, though not all, of Boston's young homicide victims and offenders emerge from a universe of gang membership and activity; they are high-rate criminal offenders ${ }^{68}$ who are known to local authorities, institutionally and personally, and they move in a universe of gang membership, geography, antagonisms, and alliances which, while complicated, is to a considerable extent apprehensible to close outside students. These sixty-one gangs and the three percent of the local youth they represent are clearly central players in the city's youth gun problem.

As we shall see, this was a fundamentally positive discovery, since it arguably lends itself to a powerful set of interventions that would not be effective if homicide offending and victimization were more diffusely distributed among nongang and noncriminal youth. It also raised other serious concerns, however, principally that the public and even local authorities might conclude that if youth homicide in the city consisted primarily of "players" killing one another, then perhaps it was not so great a problem after all.

The working group was prepared to say several things in response to such a reaction. First, gang members do not deserve to die, and gang members cannot be allowed to kill. Second, the community impact of the youth homicide problem was dire and was affecting both adults and young people across whole neighborhoods. Additionally, the working group sought to reiterate its basic conviction that much gang formation and youth gun acquisition and use was spurred by fear. While gang crime and gun violence is unacceptable and has to be stopped, the choice of many young people to join gangs and get guns is not impossible to understand. Once they do so, it is clear, they are at very high

67. In a recent instance, a long-time gang member was wounded by his best friend's sister's boyfriend in a cap to a dispute that had run for the better part of two years. The sister would feud with her brother and call her boyfriend in for help; the boyfriend and brother would argue and the gang member would get involved out of solidarity with his friend; that made him the boyfriend's enemy, and the boyfriend and the gang member had been shooting at each other intermittently for the duration of the dispute. Wounded and on the mend, the gang member told his probation officer he was going to kill the boyfriend. The probation officer suggested police intervention as an alternative, which the gang member accepted. He was found shot in his bed not long thereafter.

68. Gang members are involved in far more delinquent and criminal behavior than their non-gang counterparts. See, e.g., Esbensen \& Huizinga, supra note 61, at 565-87; BLOCK \& BLOCK, supra note 37, at 7; JOHN HAGEDORN, PEOPLE AND FOLKS 99-105 (1988); Jeffrey Fagan, Social Processes of Delinquency and Drug Use Among Urban Gangs, in GANGS IN AMERICA 75 (C. Ronald Huff ed., 1990); Jeffrey Fagan, The Social Organization of Drug Use and Drug Dealing Among Urban Youth, 27 CRIMINOLOGY 633 (1989); Malcolm Klein et al., The Impact of Police Investigation on Police Reported Rates of Gang and Non-gang Homicides, 24 CRIMINOLOGY 489 (1986); Maxson \& Klein, supra note 64, at 202-03; Terrance Thornberry et al., The Role of Juvenile Gangs in Facilitating Delinquent Behavior, 30 J. RES. CRIME \& DELINQ. 55 (1993).

The criminal behavior of gang members has also been described as "cafeteria-style" offending with gang members engaged in a wide range of illicit activity, ranging from minor property and disorder crimes to serious and violent offenses. Our somewhat different finding, that youth homicide victims and offenders with a high likelihood of gang involvement also display cafeteria-style offending, is nonetheless consistent. See also HAGEDORN, supra; Fagan (both), supra; Klein \& Maxson, supra. 
risk - on the order of a one in seven chance - of dying by gang violence. ${ }^{69}$ This is a dynamic for which many of the people involved are not entirely responsible and from which they should be protected. In practice, it was virtually never necessary to deploy these arguments except in response to community and agency respondents who were themselves concerned that others in the city might not be concerned about gang member-on-gang member violence.

\section{III}

\section{A Tactic and A Strategy: Coerced Use Reduction}

The facts that youth who kill and are killed are often known to the police and probation officers, act with their fellows in groups, and tend to commit a variety of crimes, often in a rather public fashion, offers a certain amount of leverage. This basic outline had long been known to the city's law enforcement authorities and had been the basis for a largely arrest-oriented strategy aimed at gang members. "The tactic," according to one gang officer, "is just to get them, get them, get them and finally build up such an arrest record that finally [the Suffolk County District Attorney's Office] will direct-indict them and put them away." ${ }^{70}$ Reconsidering these facts and the limits of the traditional enforcement approach led the Boston Gun Project Working Group to a possible strategic innovation.

On occasion, the Boston Police Department has mounted a special kind of operation when gang activity erupted into its most vicious mode, that is, when the gun homicides, assaults, and use (brandishing, expressive shooting, and the like) resulted in so many deaths and injuries and were such powerful sources of general community fear. ${ }^{71}$ These special operations have had three essential elements. One is a focus on all available legal enforcement levers. The Department's Youth Violence Strike Force, in conjunction with probation officers and other outside agencies, has pursued the aggressive maintenance of order with the gangs. Gang members are prevented from publicly dealing and using drugs, and from committing minor legal violations like driving unregistered cars and public drinking. They are forced to observe strictly their terms

69. We arrive at this estimate by noting that there are, on average, about 20 gang members killed each year, for an annual homicide victimization risk of $1.5 \%(20 / 1300=0.0154)$, or $1,500 / 100,000$. Taking a hypothetical gang membership "spell" at 9 years, between the ages of 16-24, gives us a homicide victimization risk of $14 \%$, or $1: 7$. This is, of course, crude; not all gang members are equally at risk for victimization, not all will be gang members as long (or as briefly) as 9 years, and the size of our gang pool may well change over time. It is certainly true, however, that gang membership is extraordinarily risky. Exactly how much of this risk is due to self-selection into gangs, and how much to the dynamics of gang life, remains difficult to determine.

70. Grace Suh, Violent Crime in Boston and the Response of the Boston Police Department: An Evaluation of the Anti-Gang Violence Unit (unpublished policy analysis exercise, Kennedy School of Gov't, Harvard University 1993).

71. For a discussion of gangs and gang violence as sources of community fear and dread, see JACK KATZ, THE SEDUCTIONS OF CRIME 128-38 (1988). 
of probation and parole, which can include school attendance, strict curfews, and area restrictions. Additionally, gang members are subject to service of outstanding warrants and the like. Because the members of particular gangs are fairly well known to police, probation officers, and streetworkers, and because these officials can readily gather more intelligence as required, these actions are carefully focused on active gang members and often on those gang members most deeply involved in the active disputes. Thus, uninvolved youth do not seem to be adversely affected. The second element is an explicit communication campaign, often carried out face-to-face between police officers and gang members, to deliver the message that it is violence that has provoked this unusual, heightened activity, and that it will take an end to the violence to make it stop. Third, gang mediation specialists are deployed and other social services mobilized. The gun violence seems invariably to stop. One such operation in Dorchester's Wendover Street area resulted in not only the suppression of a severe gang violence problem but also the surrender of over a dozen handguns.

While this approach has been used infrequently, we believe that it might undergird a city-wide violence and gun use reduction strategy. The aim will be to make this concerted, interagency response the norm where gang violence is concerned, to make gang members understand that this is now the case, and to back it up with a predictability, speed, and weight that will eventually prevent gang violence even when police and other authorities are not present. The goal, unlike most other enforcement-oriented "suppression" approaches, will not be to attack or eliminate gangs as such, or to prevent all gang-related crime; it will be explicitly focused on violence and violence prevention. ${ }^{72}$

To that end, the gun project working group has designed a strategy that will involve heightened surveillance for shooting and other selected incidents, and allow rapid identification of violence and violent groups. This operation will be coordinated among the agencies represented on the Boston Gun Project Working Group, with a correspondingly large menu of available interventions and sanctions (from probation curfew checks to federal prosecution). It will be implemented in close coordination with a communications strategy designed to inform at-risk youth unambiguously of the new rules applicable in Boston: no violence, or else face powerfully enhanced enforcement attention. Offending youth will not, of course, be offered protection or a "pass" for criminal activity in exchange for foregoing violence (and ordinary "baseline" police, probation, and other such activity will continue), but they will be made to understand that violence will bring swift and comprehensive attention. District patrol officers will be incorporated into each "calming" operation and will continue after the special interagency teams have moved on. If violence reoccurs, the interagency focus will be renewed.

72. See Malcolm W. Klein, Attempting Gang Control by Suppression: The Misuse of Deterrence Principles, in THE MODERN GANG READER 88-111 (Malcolm W. Klein et al. eds., 1995). 
In effect, the police and other authorities are admitting that they cannot quell all the illegal activity connected with gangs everywhere in the city, all of the time. They will, however, be making it plain to gangs that they can stop it at any particular place at any particular time ${ }^{73}$ and that violence will henceforth be the chief determinant of how those resources are allocated. ${ }^{74}$ Interestingly, this policy will move any impact of the strategy beyond both gun violence and youth violence to include gang violence as such, with prospective impact on both gun and nongun violence committed by older gang members as well.

\section{A. Communicating the Strategy: Marketing Deterrence}

The working group's policy is, in its broadest sense, a classic deterrence strategy. ${ }^{75}$ Boston's authorities will not be able to prevent gang violence unless gang members believe that unpleasant consequences will follow on violence and gun use and choose to change their behavior. It is thus crucial that gang youth

73. Research has found that police officers can be successful in shutting down illicit activity in specific high crime areas. Specifically, intensive law enforcement efforts have been found to be effective in controlling drug markets and hot spots of firearm violence. See KENNEDY, CONTROLLING THE MARKET, supra note 22, at 4-8; Lawrence W. Sherman \& Dennis P. Rogan, The Effects of Gun Seizures on Gun Violence: "Hot Spots" Patrol in Kansas City, 12 JUST. Q. 755 (1995); David Weisburd \& Lorraine Green, Policing Drug Hot Spots: The Jersey City Drug Markets Analysis Experiment, 12 JUST. Q. 711 (1995).

74. When this portion of the strategy was presented to the Boston Police Department command staff, one senior officer observed that this was a familiar idea. In fact, it is what the department has always done when a police officer is wounded. This raises the interesting question of how, in fact, it became a norm in criminal circles that police officers were for the most part off limits. One suspects that his account explains this.

75. Much of the literature evaluating deterrence focuses on the effect of changing the certainty, swiftness, and severity of punishment associated with certain acts on the prevalence of those crimes. See, e.g., Samuel Cameron, The Economics of Crime Deterrence: $A$ Survey of Theory and Evidence, 41 KYKLOS 301 (1988); Philip J. Cook, Punishment and Crime: A Critique of Current Findings Concerning the Preventive Effects of Punishment, 41 LAW \& CONTEMP. PROBS. 164 (Winter 1977); see also Steven D. Levitt, Why Do Increased Arrest Rates Appear to Reduce Crime: Deterrence, Incapacitation, or Measurement Error?, Working Paper \#5268 (NBER, 1995) (focusing on arrest rates rather than sanctions by looking at arrest rates using aggregate data); Raymond Paternoster, The Deterrent Effect of the Perceived Certainty and Severity of Punishment: A Review of the Evidence and Issues, $4 \mathrm{JUST}$. Q. 101 (1987); Lawrence W. Sherman \& Richard A. Berk, The Specific Deterrent Effects of Arrest for Domestic Assault, 49 AM. SOC. REV. 261 (1984) (looking at experimental evidence on the effect of arrests for domestic violence on repeat offending).

In addition to any increases in certainty, severity, and swiftness of sanctions associated with youth violence, we also hope to gain deterrence through the advertising of the law enforcement strategy, and the personalized nature of its application. The effective operation of general deterrence is dependent on the communication of punishment threats to the public. As Zimring and Hawkins observe, "the deterrence threat may best be viewed as a form of advertising." FRANKLIN E. ZIMRING \& GORDON J. HAWkINS, DETERRENCE: THE LEGAL THREAT IN CRIME CONTROL 142 (1973). One noteworthy example of this principle is an evaluation of Massachusetts' 1975 Bartley-Fox amendment, which introduced a mandatory minimum one-year prison sentence for the illegal carrying of firearms. The high degree of publicity attendant upon the amendment's passage, some of which was inaccurate, was found to increase citizen compliance with existing legal stipulations surrounding firearm acquisition and possession, some of which were not in fact addressed by the amendment. See James A. Beha II, And Nobody Can Get You Out: The Impact of a Mandatory Prison Sentence for the Illegal Carrying of a Firearm on the Use of Firearms and on the Administration of Criminal Justice in Boston-Part I, 57 B.U. L. REV. 96 (1977). 
understand the new regime that the city is seeking to impose. Boston's agencies can do a great deal to communicate likely consequences and intended results, as well as explain various actions as the strategy unfolds, to the target audience. Selecting messages and avenues to "advertise" the new regime will thus be an essential part of the larger strategy.

There are various communication routes available. One is probation officers: many of the gang members are on probation, most gangs have a member on probation, and virtually all gang members interact with probationers. The working group intends to use probation officers both to get out the basic use reduction message and to update gang members as the strategy proceeds. Another is semiformal meetings between the authorities and gang members, with gang members invited to attend if they are willing or, again, required to attend as a condition of probation. Adult and juvenile correctional facilities offer literal captive audiences. Other possibilities exist as well. In all cases, the working group intends to communicate the same basic themes. At the outset of the intervention, the message will be, essentially, that it is a new game in town where violence is concerned; that the authorities intend to respond to violence in a rapid, powerful, concerted, and predictable fashion; that all the authorities represented on the working group are sharing information and intelligence regularly; that violence will bring the imposition of a wide variety of sanctions; and that various kinds of help are available for those who wish it. As the intervention proceeds, the message will address its implementation and the logic thereof: "Gang $\mathrm{X}$ broke the rules and this is what happened to them; this is how we're making our decisions, and how to keep the same thing from happening to you."

\section{B. Triggering Intervention}

One interesting aspect of designing this approach has been considering what should count as the sort of event that triggers such intervention. Gun homicides and assaults clearly count but are, fortunately, relatively rare. Gun possession and carrying should probably count, but they are hard to ascertain. Furthermore, until some effective way to force kids to turn in their guns is developed, ${ }^{76}$ a focus on possession and carrying would require simultaneous intervention for most or all of the gangs in the city, which is clearly impractical. The correct triggers appear to include the following: gun homicide, assault, brandishing, and firing; knife and other homicide and serious assault; and

76. One gun recovery strategy the working group is considering incorporating into its larger strategy is the consensual search program developed by the St. Louis Police Department. See Richard Rosenfeld \& Scott H. Decker, Consent to Search and Seize: Evaluating an Innovative Youth Firearm Suppression Program, 59 LAW \& CONTEMP. PROBS. 197 (Winter 1996). In the Boston strategy, attempts to win parental approval to search for firearms would be focused on known gang members as part of focused "calming" interventions, and information that violence would bring such attention would be delivered to gang members as part of the strategy's overall communications effort. 
possibly other violent and fear-producing behavior to be assessed on a locale-bylocale basis.

\section{Displacement and Gang Rivalries}

Unlike most enforcement strategies, displacement ${ }^{77}$ is in this instance implosive rather than explosive: When authorities suppress gang activity, and perhaps especially when police disarm gangs, it attracts violence to those gangs from rival gangs. This is felt acutely by gang members themselves. Boston Police Department gang officers report fervent requests by gang members in, for instance, the recently "calmed" Wendover Street area that police not leave once they have restored order in the area because these kids fear attention from their nearby Magnolia Street rivals.

Here, the map of gang rivalries and alliances will play an important part. When the police and others intervene to quell gang violence and gunfire, the map will be used to determine the next stop for the intervention team. For instance, if Wendover is calmed, Magnolia should be warned that they are under particular scrutiny; if Magnolia needs to be calmed, Humboldt, Fayston, and Walnut Street should be warned, and so on (Figure 5). If the peace is broken, it will be picked up by the district maintenance team, by community sources, and in incident reports, and the calming operation will be renewed. The hope is to protect not only the youth in the Wendover and Magnolia gangs, but also the peace that the strategy brings to those areas.

\section{The "Firebreak" Hypothesis}

It is important to note that the use-reduction strategy is designed to work at two levels. It is intended to prevent, or shorten, active gang conflicts. More importantly, it is intended to interrupt the currently self-sustaining cycle of fear, weapon acquisition and use, and violence that we hypothesize to be driving youth violence in Boston. If gang violence can be prevented for some meaningful period, the youth violence problem may reestablish itself at a new and lower equilibrium, as youths' fear, use of weapons, and violent behavior all attenuate. In the language the Gun Project Working Group came to use, a period of reduced violence could act as a "firebreak" across the current violence dynamic. The larger hope, then, is that a successful intervention to reduce gang violence in the short term will have a disproportionate, sustainable impact in the long term.

This use-reduction strategy is, alone, potentially powerful. Any measures to impede youthful offenders' access to firearms could only strengthen it. To this question, we now turn.

77. Displacement is the shifting of the incidence of crime to another forum, time, or locale. Thomas A. Repetto, Crime Prevention and the Displacement Phenomenon, 22 CRIME \& DELINQUENCY 166 (1976); see also Robert Barr \& Kenneth Pease, Crime Placement, Displacement, and Deflection, in 12 CRIME AND JUSTICE: A REVIEW OF RESEARCH 277 (Michael Tonry \& Norval Morris eds., 1990). 
IV

THE SUPPLY SidE: BOSTON'S ILliCIT GUN MARKET

\section{A. Views}

As with the nature of youth violence, there were, at the outset of the Boston Gun Project, certain widely held beliefs among practitioners concerning the nature of the illicit markets that supplied youths with guns. These were more or less as follows: Youthful offenders' guns were being "run" up from Southern states with lax gun laws; the typical mode of gun trafficking was a rather largescale gun-running operation; and kids wanted new semiautomatics only one or two steps from retail sale (guns "new in the box," as police and probation officers put it), primarily in the higher-powered "weapon of choice" calibers of $9 \mathrm{~mm}$ and .380. The half-dozen or so major trafficking cases in Boston since the late 1980s fit this picture, suggesting to many that the basic shape of trafficking in the city was of rather high-volume, interstate gun runners.

Agents from the Bureau of Alcohol, Tobacco, and Firearms ("BATF") who did undercover investigations in the city believed, however, that at least half of the Boston market was supplied by very small episodic diversions such as straw purchasers who dealt only one or two guns at a time, often infrequently. Further, they believed that such "traffickers" received essentially no enforcement attention. Finally, it was widely felt that gang members shared guns among themselves, making the stockpile they held effectively much larger than a raw count would indicate.

Interviews with youthful probationers made clear that guns are fairly easy to obtain in Boston, either by buying them illegally or by borrowing them from friends and associates. They confirmed that there is a great deal of sharing of guns in the city. Thus, although a given gang may have only one or a few guns, everyone in the gang has access to a gun if desired. This sharing seems to eliminate any need for a rental market, which had been reported in Boston but does not in fact seem to exist. Unlike adult felons, youthful offenders seem to prefer new (rather than used or stolen) guns. They regularly use the phrase "new in the box" to describe the last gun they bought.

The interviews also revealed that youth do not get guns from house burglaries. There seem to be two reasons for this. First, they prefer more modern and stylish semiautomatic weapons (which entered civilian stockpile in volume only in the $1970 \mathrm{~s}$ and $1980 \mathrm{~s}^{78}$ ) rather than the older revolvers most readily available through burglary and the used market. ${ }^{79}$ Second, street

78. GARY KLECK, POINT BLANK: GUNS AND VIOLENCE IN AMERICA 72 (1991).

79. There is some evidence that gang members, in particular, seek more sophisticated and powerful weaponry than their rivals. Gang members attempt to acquire numerous guns and greater firepower in the belief that winning the "arms race" will increase their personal protection and reduce their likelihood of victimization. See RUTH HOROwITZ, HONOR AND THE AMERICAN DREAM (1983); Del 
wisdom suggests that a bargain (often stolen) gun may have "a body" on it, and they wish to avoid being caught and charged with crimes they personally did not commit. They often especially want Glock and Intratec weapons. ${ }^{80}$ They also report multiple and diffuse channels for these new or nearly new weapons such as reliable local sources, small-scale episodic sources like out-of-state relatives, and friendship networks willing to trade a gun or gun purchase for drugs.

\section{B. Boston Gun Traces}

Fortunately, the data existed to test at least some of these propositions. Since 1991, the Boston Police Department and the BATF have been tracing every gun coming into police hands. ${ }^{81}$ This BATF trace data set, which incorporated Boston Police Department information with BATF trace results, turned out to be an enormously rich resource. It contains 3,543 records for guns where the age of the associated suspect is known (Figure 6) and 1,550 records for guns associated with suspects ages twenty-one and under. Unless otherwise noted, the following analyses refer to this latter pool.

The majority of charges associated with the recovery of the gun was simple possession $(1,186$, or seventy-seven percent). Two hundred sixty-nine charges, about seventeen percent, were non-possession crimes (Table 4) ${ }^{82}$ Certain

Stover, A New Breed of Youth Gangs is on the Prowl and a Bigger Threat Than Ever, 173 AM. SCH. BOARD J. 19 (1986). These qualitative insights are supported by Block and Block's quantitative research on the increasing use and lethality of firearms in gang homicides in Chicago. BLOCK \& BLOCK, supra note 37 , at 1 . Also, Hutson and his colleagues report that a major cause of gang-related homicide is the increased use of firearms, particularly semi-automatic handguns. H. Range Hutson et al., The Epidemic of Gang-Related Homicides in Los Angeles County From 1979 Through 1994, 274 JAMA 1031 (1995).

80. The authors suspect that the preference for Glock semiautomatic pistols stems from their status as the Boston Police Department's issue weapon; conversations with police officers from other big-city jurisdictions suggest that this pattern holds elsewhere. Intratec firearms are low quality but fierce looking.

81. This arrangement was put in place by retired BATF special agent David Carlson, now of Northeastem University, and is maintained by BATF Intelligence Research Specialist Diane Campbell. It appears to be the only data set of its kind presently available. The Chicago Police Department has also recently begun to trace all of its guns, as will the 17 cities incorporated into the Treasury Department's Youth Crime Gun Interdiction Initiative, established in July 1996. See Fox Butterfield, Federal Program Will Track Sales of Guns to Youths, N.Y. TIMES, July 8, 1996, at A1.

82. Our trace data set from the Boston Regulatory Office of the BATF included the following: name of the person from whom the gun was taken (if applicable); date of birth of the person from whom the gun was taken (if applicable); location of gun recovery; nature of the incident that led to the recovery; Boston Police Department incident report designator; kind of gun (revolver, semiautomatic pistol, rifle, shotgun); caliber or gauge; serial number; obliterated serial number designator (if applicable); in what state gun was first sold at retail (if available); and the date the gun was first sold at retail (if available). Other information in BATF possession, such as the name of retail outlets and the names of first purchasers, was not provided to the authors. Since this trace data set includes essentially all guns recovered by police over an extended period, it does not suffer from the major sources of bias often encountered when using trace information, such as selective tracing by police and disproportionate numbers of noncrime guns. Our data set included 1550 guns associated with persons age 21 and under: $1186(76.5 \%)$ associated with simple possession offenses; $269(17.4 \%)$ associated with "substantive crimes" such as assault, armed robbery, and homicide; and $95(6.1 \%)$ associated with other categories such as found guns. Examination of the data set shows that it is not biased by potential problems such as large seizures of guns from traffickers, large numbers of multiple recoveries, and the 
information, such as type, brand, caliber, and whether serial numbers had been obliterated, was available for all 1,550 firearms. Other kinds of information-the state in which the guns had first been sold at retail and the date on which they had been sold-were available only for the 809 firearms BATF could trace to FFLs, first retail purchasers, or both. We will call these traceable firearms (Table 5). Analysis of the 1,550 guns recovered from youth age twenty-one and under during the five years clearly showed that most had been picked up in the same neighborhoods most suffering from the symptoms of youth gun violence (youth homicide, high ratios of gun woundings to knife woundings, shots fired, gangs, and high incidence of serious crime).

1. What Kind and What Caliber? More than eighty percent of the firearms recovered from youth were handguns, and over half of all firearms were semiautomatic pistols (Table 6). Calibers were fairly widely spread among, in descending order, $.22, .25,9 \mathrm{~mm}, .38, .380, .32$, and 12 gauge, all of which represented at least five percent of the total. The top five calibers made up seventy-one percent of all guns (Table 7). Both of the top calibers, .22 and .25 , were relatively small and low-powered.

2. What Make of Guns Are They? Since semiautomatic handguns were clearly the youth weapon of choice, we examined which brands were most represented. Only five brands of semiautomatic pistols represent nearly half the semiautomatic pistols recovered (Table 8). Whether this represents price, availability, style, or size concerns is unknown. It is useful information, however, for such things as watching for multiple purchases of guns and for informing street enforcement operations such as reverse stings. ${ }^{83}$ It is also a warning to take survey and ethnographic findings about youth gun preference with a grain of salt. Boston kids may indeed prefer (as they say they $\mathrm{do}^{84}$ ) Glock and Intratec weapons, but they tend actually to possess other guns.

\footnotetext{
like. Since June 1994, BATF has not traced guns manufactured prior to 1985; since March 1995, BATF has not traced guns manufactured prior to 1990 . The latter restriction does not materially affect this data set, which runs through May 1995 and thus contains very few traces submitted between March and May of that year. The former restriction may; guns rejected as "Unable to Trace," an omnibus BATF category including guns rejected under the prior-to-1985 rule, jumped from $16 \%$ of all traces between January and June of 1994 to $28 \%$ of all traces between July and December of 1994 . This may bias our time to crime estimates and source-state breakdowns slightly toward guns less than 10 years old, but should not influence comparisons between different offender age and crime type categories. The trace data set still, of course, represents guns recovered by the police, and is not a perfect sample of guns used in crime. Except where noted, all analyses reported in this paper are for the period January 1991 to May 1995.

83. A firearms reverse sting would involve, for example, an undercover officer selling disabled firearms to gang members known to be in the market for guns; it would obviously be useful in such an enterprise to know what firearms were in demand on the street. This remains a hypothetical tactic and has not been used in Boston.
}

84. See supra note 81 and accompanying text. 
3. Where Do the Guns Come From? Contrary to the belief of most in the local law enforcement community, a source-state analysis of traceable guns showed that a plurality originated in Massachusetts. A full thirty-four percent of traceable guns were first sold at retail in Massachusetts (Table 9). The next largest source state was Georgia, with eight percent. No other southern state broke five percent, and all Southern states combined add up to only thirty-one and a half percent. All contiguous and New England states (excepting Massachusetts) add up to less than fifteen percent. Boston had, unexpectedly, both a local and a "southern pipeline" firearms problem.

4. How Old Are They? A "time-to-crime" analysis (a measure of the time between the first retail sale of the gun and the date at which it came into police hands) of traceable guns (more accurately, in this case, a "time to recovery" analysis) shows a distinctly skewed distribution. Fully sixteen percent of traceable guns were recovered by police when the guns were less than a year old, and another ten percent when they were between a year and two years old; thus, slightly more than a quarter of traceable guns were recovered when they were less than two years old. Recoveries of guns by each additional year of age then fall steadily. At the opposite extreme, a total of thirty-one percent of traceable guns were ten years old or older.

Examining the time-to-crime for types of guns points to a faster flow of semiautomatic weapons. More than forty percent of traceable semiautomatic pistols show a time-to-crime of less than two years, with only fourteen percent being ten years old or more. Traceable revolvers, by contrast, appear as only five percent in the two-years-or-less category and sixty percent in the ten-yearsor-more category. Traceable shotguns (seventeen percent and thirty-two percent) and rifles (sixteen percent and forty-five percent) fall in the middle (Figure 7).

A more fine-grained analysis of the first two years' 215 "fast" guns also shows a skewed distribution, with half of these guns falling into the first eight months. Nearly all of these guns (180, or eighty-four percent) are semiautomatic pistols, which move slightly faster (Figure 8). And a brand analysis of those "fast" guns shows a preponderance of the top-five "favorite" makes.

"Fast" guns showed distinct caliber characteristics. Here, the higherpowered $9 \mathrm{~mm}$ and .380 dominate markedly, together representing more than half of the entire pool, and the top five calibers comprise nearly eighty-four percent of all guns (Table 7).

It should be emphasized that these time-to-crime distributions cannot, by definition, incorporate guns that the BATF was unable to trace to an FFL. Many of these were simply too old to trace. Thus, these figures overestimate the proportion of new guns and underestimate the skew of the distribution. This holds for all time-to-crime distributions presented in this paper. However, these distortions appear to be less significant for youths' guns than for adults' guns. There are two BATF trace categories broadly indicative of pre-1968 
manufacture, "too old to trace" and "no serial number." 85 We examined both youths' guns and guns recovered from those age thirty and over. We removed from each pool guns with obliterated serial numbers ${ }^{86}$ and estimated the pre1968 guns as a proportion of each pool. Seventeen percent of youths' guns, versus twenty-two percent of adults' guns, were pre-1968. ${ }^{87}$ This suggests that the propensity toward newer guns found in traceable youths' guns also holds across the whole pool of guns recovered from youth.

Finally, we examined the time-to-crime of some particularly popular semiautomatic pistols. Some of these showed even brisker patterns (Figure 9). Fifty-five percent of traceable Davis pistols showed time-to-crime of less than two years, and seventy-two percent of less than three years. Ninety percent of traceable Lorcin pistols showed time-to-crime of less than two years. Fifty-five percent of traceable Bryco/Jennings pistols showed time-to-crime of less than two years. Traceable Raven pistols, by contrast, moved less quickly, with sixteen percent in the first two years and twenty-eight percent ten years old or more.

Here, then, was a partial qualification, and a partial yet very important validation, of the impressions of practitioners and the statements of youth interviewees. Not all guns were "new in the box" semiautomatics. But more than a quarter of all traceable guns recovered by police were less than two years old, and the newest of those guns both moved rapidly to the streets and into police hands and were overwhelmingly the semiautomatics-many of them 9 $\mathrm{mm}$ and .380 caliber-practitioners and interviewees identified as "problem" guns or "guns of choice."

This was, fundamentally, good news, for the simple reason that the newer a gun is, and the fewer hands it has passed through, the easier it is to investigate its diversion and its diverters and to mount prosecutions. This is one way in which the illicit gun market is fundamentally different from drug markets: There is, albeit sometimes at considerable temporal remove, paperwork on guns. $^{88}$ The BATF can often find out where a gun was manufactured or imported, where it was first sold at retail, and who bought it. Investigations can

85. "Too old to trace" is a BATF category reserved for pre-1968 firearms. "No serial number" generally, but not invariably, indicated pre-1968 manufacture. Exceptions would include certain post1968 foreign firearms subsequently brought into the United States, post-1968 domestic firearms improperly manufactured without serial numbers, and police department coding errors on trace requests, particularly with regard to obliterated or difficult-to-locate serial numbers. These exceptions are uncommon. Interview with Lennie Ladd, Special Agent, Boston Regulatory Office, BATF (Jan. 1996).

86. As we will discuss below, youths are found in possession of guns with obliterated serial numbers at a higher rate than adults, and there are other reasons to believe that these guns are relatively new.

87. This analysis is drawn from David M. Kennedy et al., Gun Buy-Backs: Where Do We Stand and Where Do We Go?, in UNDER FIRE: GUN BUY-BACKS, EXCHANGES, AND AMNESTY PROGRAMS 148 (Martha R. Plotkin ed., 1996). An analysis of guns recovered as part of two Boston buy-back programs suggests that they bear relatively little resemblance to possession and substantive crime guns recovered from either youths or adults.

88. The most meaningful exception to this rule is for guns stolen from FFLs. Even here, however, the BATF can trace the gun from the manufacturer to the FFL in question. 
be built on that information, whether the object is to uncover a particular lowvolume straw purchaser or identify a large trafficking operation. And for investigative purposes, the newer the gun is the better: Records are likely to be better and more available; individuals listed on paperwork are easier to find; guns are less likely to have been resold, given away, or stolen; and the chain of transfer to illicit consumers is likely to be shorter. A ten-year-old .38 revolver is likely to be an investigative dead end. A six-month-old $9 \mathrm{~mm}$ semiautomatic, by contrast, holds promise.

One cannot tell from these data whether the flow of "fast" guns is the product of, at one extreme, a few high-volume gun traffickers or, at the other, a multitude of small-volume straw purchasers. If, however, one believes that interstate gun trafficking requires at least a modicum of organization and capital, then there is evidence that the "fast" guns may be the product of such higher-volume trafficking. Analysis of the source states of "fast" guns shows that they are more likely to be from Southern states and less likely to be from Massachusetts (Table 9) ${ }^{89}$ This is partial confirmation of the impressions of police and probation officers that the "problem" guns of "problem" youth come from out of state. This, too, is good news, since trafficking enforcement could aspire to take out these firms, based on investigations of "fast" guns, with a disproportionate impact on the overall flow of high-risk weapons. 90

5. Guns with Obliterated Serial Numbers. It is reasonable to think that an even larger proportion of youths' guns are "fast" guns. Nearly twenty percent of the guns in the five-year trace data set were untraceable because their serial numbers had been obliterated (Table 5). Nearly three-quarters of these guns were semiautomatic pistols. Most were recovered in the same neighborhoods suffering from youth gun violence, and there was a heavy representation of our familiar top five favorite brands.

We can tell neither where these guns were first purchased nor how old they are. One can, however, make inferences, particularly with regard to time-tocrime. The fact that they are largely semiautomatics suggests that they are newer rather than older simply because semiautomatics tend to be more recent additions to the civilian stockpile. It also suggests that they were purchased rather than stolen since semiautomatics are less readily available through burglary.

There are fundamentally only three reasons to obliterate a serial number: to avoid being tied to a burglary through possession of a firearm whose serial number has been reported to police; to avoid being connected to a crime gun

89. Another possibility is that local purchasers and suppliers have personal and family ties that link them with the Southern states. In actuality, most of the larger gun trafficking cases prosecuted in Boston since the late 1980 s share both characteristics. They featured more organized gunrunners using friends and family in Southern states as an opportunity to acquire firearms.

90. For more evidence that relatively new guns are used disproportionately in crime, see Franklin Zimring, Street Crime and New Guns: Some Implications for Firearms Control, 4 J. CRIM. JUST. 95 (1976). 
one has purchased legally; and to avoid being identified through BATF records as the straw seller, or buyer, of a gun with paperwork on it. Only the third reason is likely to apply here. ${ }^{91}$ Having hard information on the times-to-crime of guns with obliterated serial numbers might thus shift the time-to-crime profile of our gun pool toward faster-moving guns, particularly among semiautomatic pistols.

To the extent that these guns can have their serial numbers restored, which is sometimes technically feasible, they will be open to enforcement attention, and should clearly receive it. For instance, a top-five make semiautomatic pistol from Georgia recovered in Roxbury with an obliterated serial number is probably a prime candidate for investigation and enforcement. Both the seller and the buyer of the weapon seem likely to be more serious offenders.

6. "Possession" versus "Substantive Crime" Guns. We performed these same analyses separately for the 1186 guns associated with simple possession charges ("possession" guns) and the 269 guns associated with non-possession crimes ("substantive crime" guns) included in the trace data set. ${ }^{92}$ Certain important differences emerged. The type of gun associated with substantive crimes was somewhat less likely to be a semiautomatic pistol or a revolver, with the substitution largely to shotguns. The proportion of in-state guns jumps markedly, and that of the combined southern states drops somewhat (Table 10). The proportion of guns with a time-to-crime of two years or less drops slightly (Figure 10). Most interesting is a fifty percent reduction in guns with obliterated serial numbers (Table 10). All of these changes with regard to substantive crime offenders are in keeping with an image of a better-connected criminal with a tools-of-the-trade outlook toward weapons, a willingness to use long guns, and more likely to use older and stolen weapons.

These findings are in keeping with the idea that there are less and more serious consumers of illicit firearms, that different types of consumers have different acquisition patterns, and, as has already been noted, they diminish the promise of a market disruption strategy to reduce youth gun violence. If the most serious youth offenders use firearms that are older, more likely to be long guns, and more likely to be stolen, the impact on them of a trafficking enforcement strategy will be less powerful.

However, if those youth with the most serious criminal intent, as measured by their behavior, show this pattern of gun acquisition, then the fact that other, presumably less serious youth show a different pattern is in keeping with the notion that there is something other than serious criminal intent driving their

91. It is logically possible, of course, that our obliterated guns include weapons that were obliterated years ago and are only now turning up in the hands of youth. The type and brand distribution of these guns suggests that this is not in fact the case.

92. When examining firearms characteristics associated with possession and substantive crimes, we omit firearms not explicitly linked in our data set with one of these categories $(95$, or $6.1 \%$, for those 21 and under). 
gun acquisition. Possibly, as hypothesized, the driving force is the fear/selfdefense/youth culture dynamic. At least part of this dynamic is currently being driven by the ready availability and the widespread possession, carrying, brandishing, and firing of firearms: not only by actual firearms assaults. And to the extent that that dynamic can be interfered with by interfering with gun trafficking, a market disruption strategy remains a logical pursuit.

7. Adults' Guns. An important question is whether there are distinct youth and adult gun markets. As one indicator, we analyzed older populations in the Boston Police Department/BATF trace data set, broken down into simple possessors and substantive crimes (Table 10). Those twenty-two to twenty-nine years old showed relatively minor differences when compared to youth. Those thirty years old and up, however, were quite different. ${ }^{93}$

Older possessors were less likely to have semiautomatic pistols (much less likely in the case of substantive crime offenders) and more likely to have long guns, especially in the case of substantive crime offenders. Adult possession offenders fell between youth possession and youth substantive crime offenders on the likelihood that their guns were first sold at retail in Massachusetts, but fully sixty-five and a half percent of adult substantive crime offenders had guns from Massachusetts (and only 12.7 percent from southern states). Both adult classes also had strikingly low rates of obliterated serial numbers. This last fact, particularly in conjunction with the existing research linking serious adult felons to stolen guns, adds weight to the idea that the high rate of serial number obliteration among youth is a sign that they are acquiring new guns only a few steps from first retail sale. Finally, both youth categories, possession and substantive crimes, showed faster overall time-to-crime for traceable guns than both adult categories (Figure 10). ${ }^{94}$

The differences between adults and youths suggest that the illicit market that supplies guns to youths is peculiarly open to enforcement attention. Youthful offenders' high proportion of handguns, particularly semiautomatics, the quicker time-to-crime of their guns, and their high proportion of obliterated serial numbers all suggest the higher relative importance of a flow of relatively new

93. A far larger proportion ( 446 or $39.4 \%$ ) of the 1132 guns associated with persons 30 and over are neither "possession" guns nor "substantive crime" guns. More than $60 \%$ of these are guns taken by police for "safekeeping," a practice followed by many departments when they find adults in the possession of guns officers feel may be a hazard to the possessors or to others (typical circumstances would include domestic disturbances, DUI traffic stops, and the like). We have excluded these guns from our analysis of possession versus substantive crimes.

94. On all these counts, plus-by definition-a propensity toward committing (or at least being arrested for) serious crimes at relatively advanced ages, these adult substantive crime offenders look very much like those Wright and Rossi identified in their 1986 research as "handgun predators." WRIGHT \& ROSSI, supra note 10 , at 39 . This is clearly the group least likely to be affected by gun market disruption strategies. However, to the extent that, as seems the case, the general idea of gun market strategies has been neglected because of the difficulty of preventing gun acquisition by such serious older offenders, it is worth noting that our other classes of offenders, including adult possession offenders, show patterns of acquisition that look more promising. Not all offenders are handgunpredator type offenders, and gun market strategies should not be judged as if they are. 
weapons. The discovery that youth want and obtain newer guns diminishes the single strongest reason for thinking that there is no utility in intervening in the illicit market. Boston's youths' guns-any of them, at any rate-do not appear to be stolen. ${ }^{95}$ That is reason for considerable hope. ${ }^{96}$

\section{Sheley and Wright Revisited}

These findings suggest a revisiting of Sheley and Wright's conclusion that most juveniles' guns are stolen and that diversion of firearms from retail sources does not constitute a problem. ${ }^{97}$ Several possibilities exist for the difference between their conclusion and ours.

One possibility is that the frames of the studies are different. Sheley and Wright looked at legal juveniles in four urban areas, whereas we are looking at those twenty-one years old and under in only one urban area. Differences in age groups and in city-specific gun acquisition behavior could account for the differences in results.

Another possibility is that the categorization procedures typically followed in surveys of illicit gun acquisition obscure the actual sources of the firearms in question as well as the relative importance of those sources. Julius Wachtel notes the "vexing problem" that in such surveys "straw purchases are typically not assigned to a discrete category," thus minimizing the significance of transactions only one or a few steps from first retail sale.

Instead, these cases are usually deconstructed so that they fall into whatever class seems to offer the best fit (for example, "family and friends"). Purported buyers thus become both a gun's proximate source as well as its origin. This practice deflates retail statistics and obscures the potential significance of surrogate transactions (that is, straw purchases). ${ }^{98}$

This process is clearly at work in Sheley and Wright's analysis. Six percent of the inmates and twenty-three percent of the students they surveyed indicated

95. BATF does inquire about stolen guns; the status of $3448(80 \%)$ of 4,293 firearms in their database was checked with the National Crime Information Center ("NCIC") and the Treasury Enforcement Communications System ("TECS"). Only 4\% (141) of the entire data set were reported stolen. For firearms associated with adults (ages 22 and older), $2.7 \%$ (46 of 1691) were reported stolen; stolen firearms associated with youth were somewhat higher at $4.2 \%$ (50 of 1177). However, since many stolen guns are never reported to authorities, it is impossible to know how close these figures are to reality.

96. We have emphasized that to our knowledge our findings are Boston-specific. Still, other studies of youths' firearm use and preference-while not fully compatible with our analysis-appear congruent. Block and Block's study of gang homicide in Chicago found both an increase in gun use and an increase in the use of semiautomatics between 1987 and 1990. BLOCK \& BLOCK, supra note 37 . It should be noted that the Blocks studied homicide, not possession, and found a greater increase in the use of largecaliber weapons, some but not all of which would have been semiautomatic. Id. Sheley and Wright found semiautomatics and revolvers roughly equal in popularity among incarcerated juvenile felons; while they could not examine the age of these weapons, the semiautomatic weapons would likely have been newer, for reasons discussed above. The students they surveyed were somewhat more likely to own semiautomatics. See SHELEY \& WRIGHT, supra note 7, at 7.

97. See supra notes 21-23 and accompanying text.

98. Julius Wachtel, Sources of Crime Guns in Los Angeles, California, Paper presented at the annual meeting of the Academy of Criminal Justice Sciences 11 (Mar. 14, 1996). 
that they had obtained their most recent handgun from a family member. Thirty percent of inmates and thirty-eight percent of students obtained their most recent handguns from a friend. It is simply not possible to unpack from their data how many of these guns entered illicit channels through theft or retail purchase. It is impossible to tell, from Sheley and Wright's study, the age of these handguns. It is likely, in fact, that many of those surveyed did not themselves know how their guns entered the illicit market. It is clear, however, that a substantial proportion of the "family and friends" transfers represent illicit trafficking of guns close to first retail sale. Sheley and Wright note that

a total of 32 percent of the inmates and 18 percent of the students had asked someone to purchase a gun for them in a gun shop, pawnshop, or other retail outlet; 49 percent of the inmates and 52 percent of the students mentioned a friend as the person requested to buy a gun; and 14 percent of the inmates and 18 percent of the students had turned to family members. ${ }^{99}$

Some of these juveniles' guns were thus purchased for them from retail outlets by straw purchasers; others entered illicit pipelines through purchase at retail and then made their way to them quickly but after passing through more than one set of hands.

It is, as we have noted, impossible to tell from Sheley and Wright's survey research, and perhaps from any survey research, the magnitude of this kind of close-to-retail diversion. Based on their own findings, however, it seems unreasonable to conclude, as they do, that attention to retail diversion would be fruitless because "[juveniles] rarely obtain their guns through such customary outlets." ${ }^{100}$ This is true only if one takes the narrowest possible construction of "obtain," that is, direct purchase at retail by the juveniles themselves. Taking only a slightly broader construction, the problem could become much greater, and attention to it much more productive.

\section{$\mathrm{V}$ \\ DISRUPTING THE MARKET}

Based on this information, the working group has identified a number of steps to impede the functioning of Boston's illicit gun market. Completely shutting down the illicit gun market is and will remain an impossibility. It is simply too easy to divert firearms from legal channels to illegal ones. However, it is clear that dealing in illicit guns in Boston is currently perceived by youths to be a largely risk-free enterprise: a perception doubtless shared by adult traffickers who provide them with guns. The working group's goal is to alter that perception markedly, particularly in the gang circles in which most youth homicides are committed, and inhibit illegal trading in guns as much as possible.

One obvious step is to focus on the "faster" part of the market. A surveillance system has been put in place to take advantage of the existing, and

99. SHELEY \& WRIGHT, supra note 7, at 6-7.

100. Id. at 10. 
critically important, tracing arrangements between the Boston Police Department and BATF. This system simply flags for active investigation every trace that shows a time-to-crime of less than thirty months. Higher investigative priority will also be given to traces showing more popular gun types, traces obtained from guns with restored obliterated serial numbers, guns from high-risk neighborhoods, and guns associated with known gang members or gang territories.

Another obvious step is to examine the trace data set for patterns involving FFLs and first purchasers. FFLs and first purchasers associated with multiple crime guns are clear investigative opportunities. In neither case can it be concluded from the data alone that a crime has been committed-traffickers could simply be favoring particular FFLs or multiple guns could be stolen from legitimate first purchasers-but traditional investigative techniques will doubtless reveal some to be illicit traffickers.

Another step, now in progress, involves linking the trace data set and investigative activities to historical information about gang membership and gang turf. The working group is currently making its way back through the fiveyear Boston Police Department/BATF trace data set and identifying which gun possessors were gang members. Locations where the Boston Police Department recovered firearms can also be coded and the results mapped. This will give two overlapping "catchment" areas: guns recovered from known gang members and guns recovered from known gang areas. The BATF can then examine these gang-specific pools of guns and traces for patterns in source states, first purchasers, and FFLs. For gangs with known alliances that facilitate common gun sources, the data can be pooled and analyzed.

The slower time-to-crime portion of the gun trade can be addressed using more traditional policing and investigative techniques. Here, it is investigative leads that are currently in short supply.

Since gun-possession and gun-trafficking penalties are relatively low (at least in the absence of serious prior criminal histories), authorities have not historically been successful in "turning" arrestees and getting information on their sources and clients. As a result, officers from the Boston Police Youth Violence Strike Force have recently begun focusing on offenders arrested on serious non-gun charges. That is, they attempt to extract gun market information from those facing heavy penalties for drug dealing and violent crimes. They report good success, with arrestees more willing to give up information on gun dealing than on narcotics and other crimes.

This technique may well also yield information on those trafficking newer guns. To the extent that Sheley and Wright's finding that juvenile gun dealers are among the most criminally active of juvenile offenders ${ }^{101}$ holds true for slightly older dealers, it seems likely that successful operations based on these

101. See supra notes $33-41$ and accompanying text. 
leads will pay benefits not only in trafficking prevention but also as a de facto dangerous offender strategy.

Insight into youth gun preferences may make aiming plausible and appealing reverse stings at high-risk gang members more effective. Of course, there are important public safety considerations with such methods. Under no circumstances should guns be put on the street by law enforcement. However, the gun project working group members feel that appropriate reverse stings may be manageable. Again, with the aim of poisoning the market (rather than the unattainable aim of shutting the market down), the group anticipates using probation officers and other channels to communicate to high-risk youth that the judicial system will now be trading in gun information and that undercover investigators and "gun dealers" are present in the city.

Under ordinary circumstances, one would anticipate that cracking down on the more easily investigable "faster" segment of the market would simply displace purchasers to older (including stolen) guns. This will no doubt occur. However, to the extent that guns become harder to obtain, prices will increase, and this substitution will not be complete. ${ }^{102}$ To the extent that the use reduction strategy is effective, it will also reduce this substitution. Finally, if our hypothesis is correct that there is a dynamic linking fear to gun acquisition, even a temporary disruption of the firearms market can contribute to interrupting that dynamic. If the interruption occurs before the market adjusts, the market disruption intervention will be productive.

\section{VI \\ EVALUATION}

What we have described so far is a strategy, developed with our assessment of Boston's youth violence problem and the capabilities of working group agencies in mind. The true test of the endeavor is whether it reduces youth violence in the city. This section outlines our plans for evaluating the Boston Gun Project.

Most experimental evaluations of crime-control interventions of the kind we propose assess impacts by comparing "treatment" areas, such as precincts or other police reporting areas, to areas of a city that were not targeted by the intervention. The comparison areas are generally selected, in advance, to be as similar as possible to the locations selected for intervention. During the period of the experiment, any activities in the comparison areas are maintained at previous levels and using prior methods. The comparison areas are used as a "control group," intended to reflect any influences that would have affected the treatment areas in the absence of the intervention. Evidence of an impact, then,

102. Also, to the extent that youthful consumers genuinely worry about guns not "new in the box" having been previously used in a crime, this too will inhibit substitution of older guns. 
is a reduced level of crime (however measured) in the treatment area relative to the control areas.

Our evaluation design departs from this standard approach. Most importantly, the Boston problem-solving enterprise was aimed at a city-wide problem (that is, at all areas of the city with a serious youth violence problem). There can be no control areas (or control gangs) set aside within the city because of the following: (1) the aim is to do something about serious youth violence wherever it presents itself in the city; (2) the target of the intervention has been defined as the self-sustaining cycle of violence in which all gangs were caught up and to which all gangs contributed; and (3) the communications strategy is explicitly intended to affect the behavior of gangs and individuals not directly subjected to enforcement attention. It will thus be impossible to compare areas and groups affected by the strategy to similar areas and groups not affected.

Further, while gang crime in Boston clearly manifests itself in geographically concentrated "hot spots," networks of gang affiliation and antagonism often do not respect hot spot boundaries, and unlike most efforts to attack such hot spots through place-focused interventions, our network-focused intervention will not necessarily be aimed at hot spots. ${ }^{103}$ Finally, rather than trying to protect certain areas or groups from the intervention, as in the traditional experimental design, the working group went to considerable effort to design an intervention that would create "spillover" effects onto other gangs and neighborhoods-through the communications strategy, interfering in active or nascent gang vendettas, fear reduction, and the like. Thus, if the intervention were entirely successful, a traditional evaluation would find no impact-youth homicide would fall in the targeted areas (due to enforcement) and in all other areas of the city (due to deterrence and a reduction in the fear/self defense dynamic, restricted gun availability, and the like).

As a result, the overall impact of the intervention will be measured by assessing changes in overall levels of youth violence in Boston relative to changes in youth violence in other similar cities over the same time period. In this design, the other cities will together act as a comparison group. The comparison group is designed to control for any national trends in violence that would have also occurred in Boston in the absence of our effort. ${ }^{104}$ Thus, changes (or the lack thereof) in youth violence in Boston relative to those observed in other cities will be taken as the result of the project.

Strictly speaking, it is important to view any impacts identified by such an evaluation as the result of the problem-solving approach rather than the result of any given tactic. We view the intervention in its most expansive form,

103. See Kennedy, supra note 58.

104. For two reasons it is not possible to rely upon older youth as a comparison group for this intervention. First, the data reveals that the trends in homicide are very different for youth relative to adults. Second, as noted above, the boundaries of the intervention are porous, and it may be expected to impact upon violence not strictly the target of the effort. 
including all of the research, strategy development, and implementation activities of the working group. We feel this is appropriate given that the specifics of the strategy and tactics were not known at the outset, but were developed as part of the process. ${ }^{105}$

In order to understand how any impacts were achieved (or, conversely, why the intervention failed), we will also consider in detail the intermediate goals of the project: disrupting illicit gun markets, reducing youth gang violence, and reducing levels of fear among youth. We will measure these by using surveys and ethnographic research, comparing pre- and post-intervention differences in Boston to other cities to the extent possible. The findings from this part of the evaluation will help us interpret any overall impact by pointing to the likely routes that yielded any impact.

Additionally, we will prepare a process history of our efforts-intended to memorialize the process of research, analysis, planning, and implementation-as a reference tool for other jurisdictions contemplating similar interventions and for students of problem solving. The process history will be based on regular site visits, participant interviews, and activity and statistical data (such as police reports and activity logs) collected by participating institutions. It will address the following issues: baseline police and other activities to address youth gun violence; the formation and functioning of the problem-solving team; research activities; the design of the intervention; the modification of the intervention during implementation; impact of local politics and local bureaucracies on the problem-solving process; necessary levels of organizational support; and impressions of participants, the community, and youth regarding the intervention's effectiveness, costs, benefits, lessons learned, and fruitful next steps.

\section{VII \\ CONCLUSION}

The Boston Gun Project is an attempt to bring a problem-solving strategy to bear on youth violence in a particular city. We wished to learn more about youth violence, youth gun violence, and gun trafficking, to craft interventions based on that knowledge, to implement the interventions, and to evaluate their impact.

The first half of that agenda appears largely on track. Gun Project participants have made important and sometimes unexpected discoveries about the nature of youth violence in Boston: the centrality of gangs and gang conflict, the criminality of both victims and offenders, and the "knownness" of high-risk individuals and groups to front-line police, probation, and gang

105. It is worth noting that, by taking this approach, we depart from much of what is known in the literature as evaluation of "problem-solving policing." See, e.g., LAWRENCE SHERMAN ET AL., NAT'L INST. OF JUSTICE, THE KANSAS CITY GUN EXPERIMENT 9 (1995). We feel that those efforts are more properly seen as evaluations not of the problem-solving process but of particular tactics. For more on this subject, see Kennedy \& Moore, supra note 9, at 274-78. 
mediation workers. They have made important and sometimes unexpected discoveries about the illicit gun market, including the importance of intrastate trafficking, the disproportionate taste of youth relative to other criminal consumers for new semiautomatic pistols, and their apparent preference for particular brands of those pistols. They have also made discoveries about the youth's disproportionate reliance, relative to other criminal consumers, on flows of guns from southern states, and especially, the significance of a large and highly investigable flow of "fast" time-to-crime weapons.

The Gun Project working group has crafted innovative use-reduction and gun market disruption schemes, and these schemes have received the operational support of participating agencies. If successful, the use-reduction strategy will help control the most dangerous and frequent of Boston's youthful violent offenders, reduce the fear felt by other youth who, as a result, are acquiring guns and other weapons, and reduce demand for guns. It should reduce the fear of violence that leads many youth to join gangs and thus reduce gang participation and promote a clearer distinction between truly dangerous offenders and those motivated by fear and the desire for self-defense. ${ }^{106}$ Disrupting the gun market will help reduce violence in both groups. A careful communications campaign will enhance the effectiveness of all parts of the strategy. It seems at least plausible that the demand-side and the supply-side strategies, together, could have the desired violence- and fear-reducing effect.

Whether the strategies can in fact be implemented as designed, how they will be adapted and modified in practice, and whether they will in fact have the desired impact, remain to be seen. The latter, of course, will be the final test of the larger problem-solving enterprise.

106. The use-reduction and gun market strategies may or may not have a powerful impact on youth homicides that do not seem closely tied to gangs and gang violence. That piece of the problem deserves separate attention, a matter to which the working group is now turning. 
APPENDIX

FIGURES 1-10

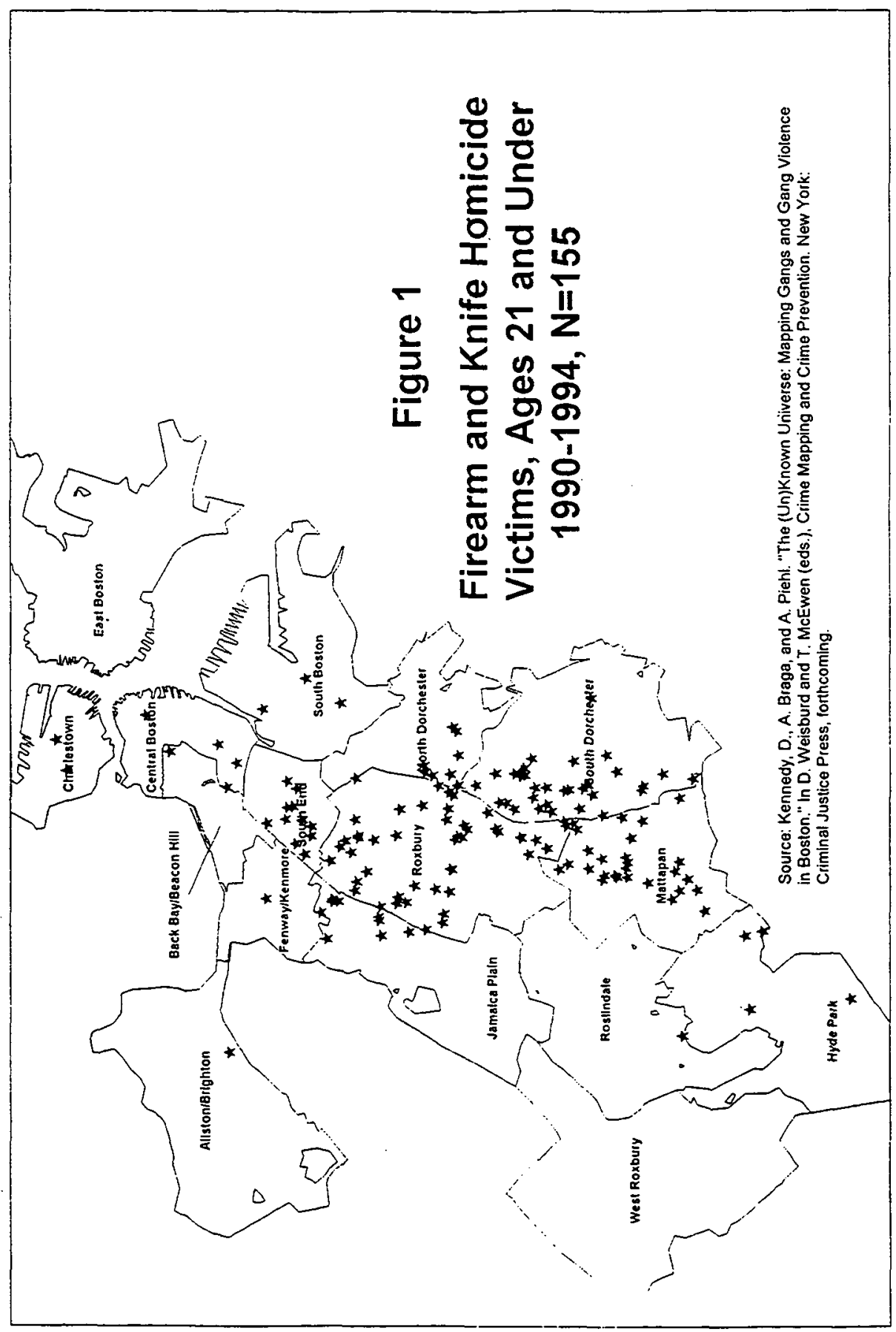


FIGURE 2

Age Distribution of GUN AND KNIFE Homicide VICTIMS, AGES 21 \& UNDER

$1990-1994, \mathrm{~N}=155$

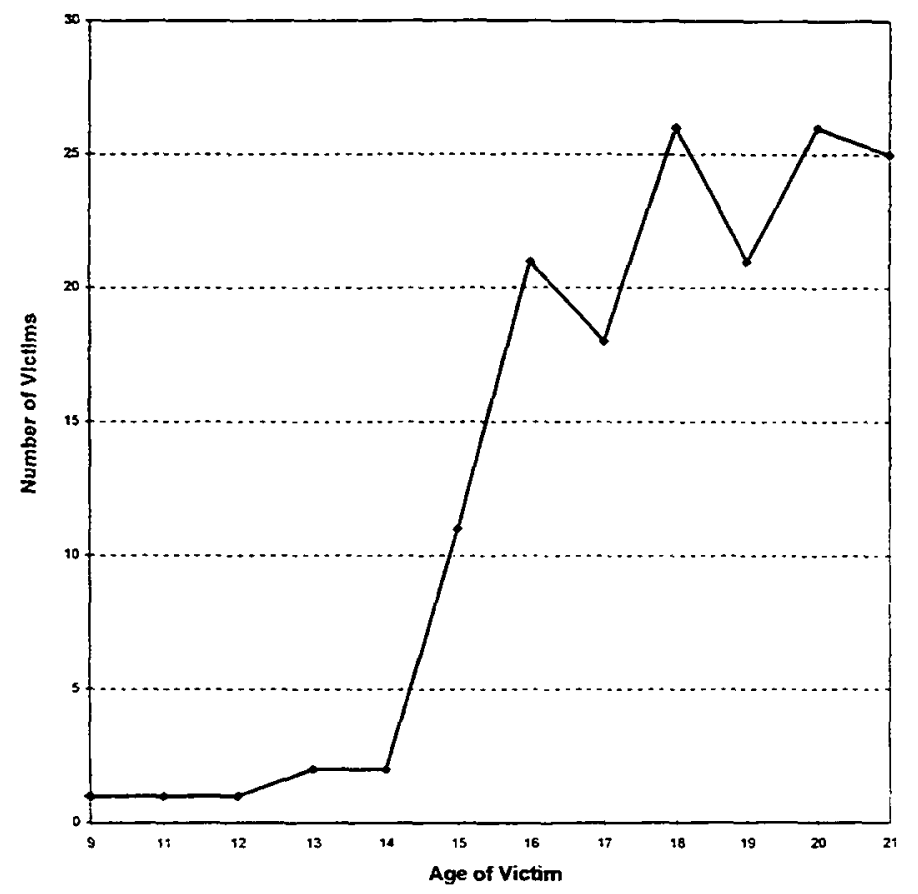

FIGURE 3

BOSTON HOMICIDE VICTIMS, 1990-1994

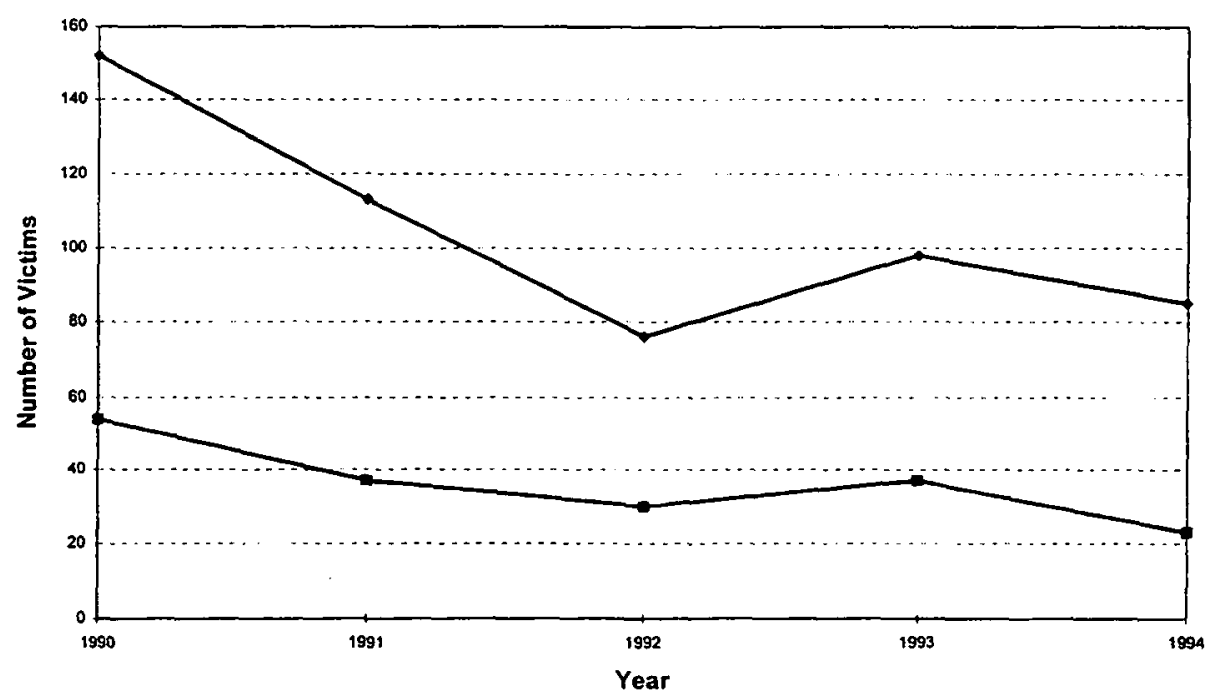




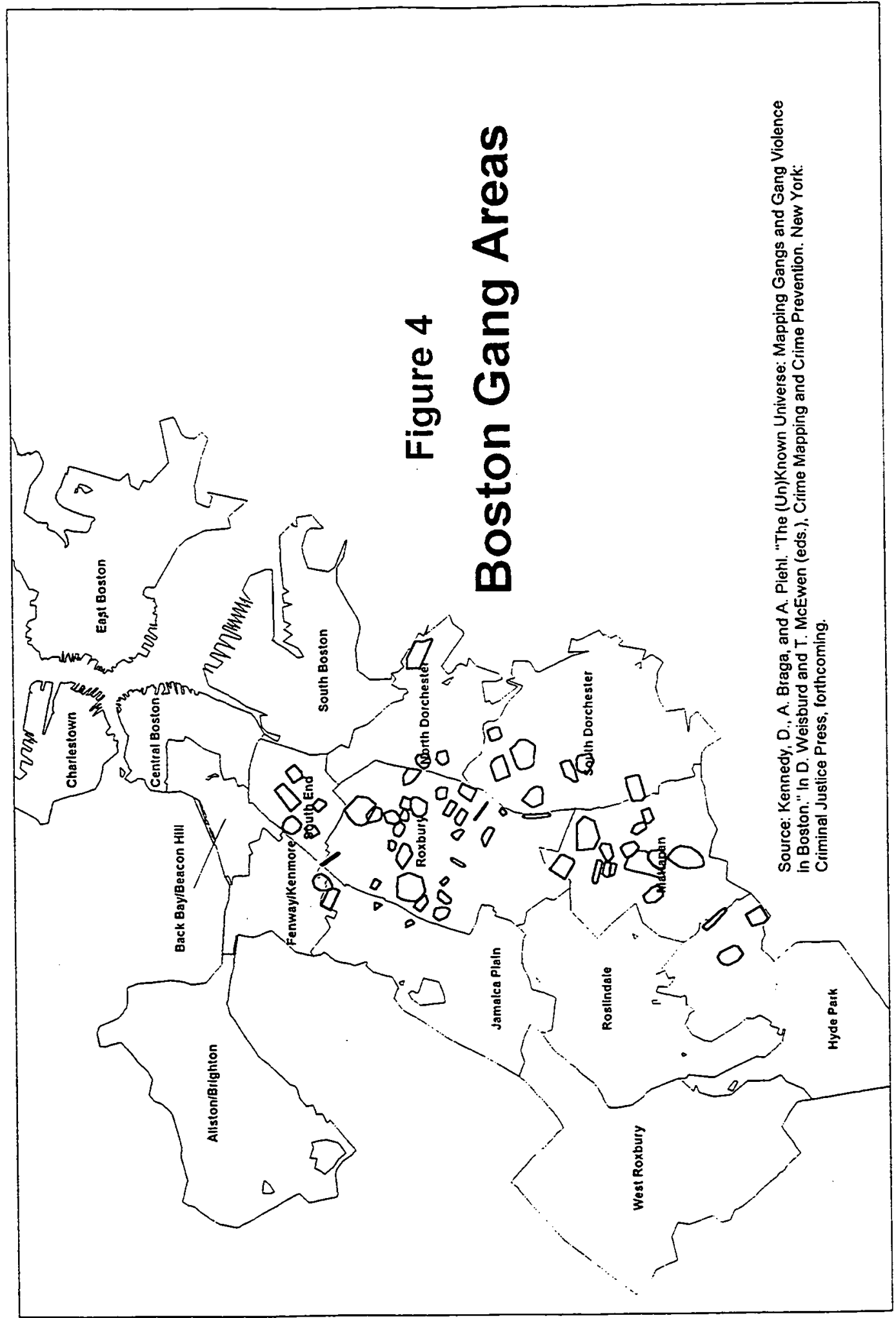




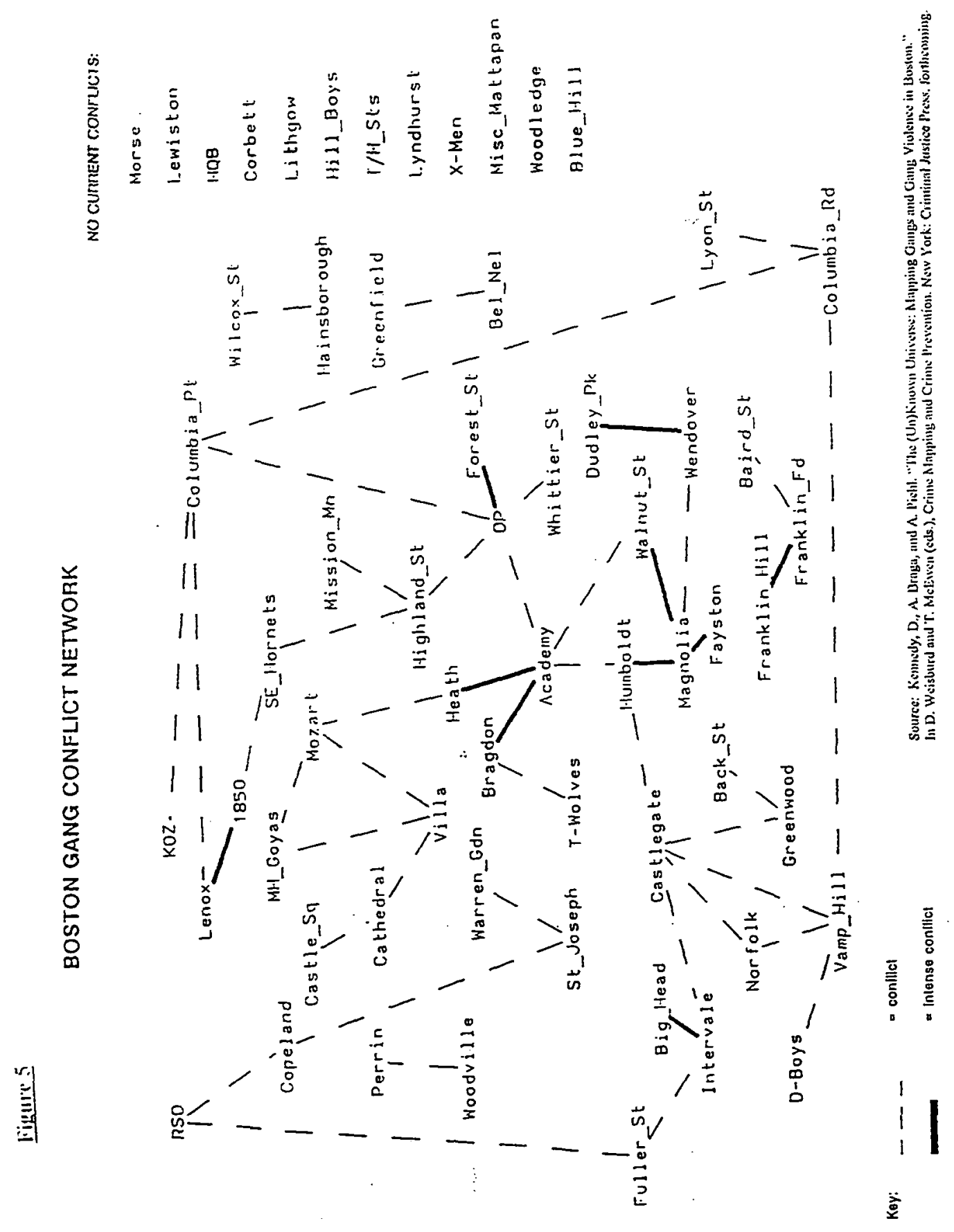


FIGURE 6

Age Distribution of OfFEnders IN ATF TRACE DATABASE, JANUARY 1991-MAY 1995, N=3,543

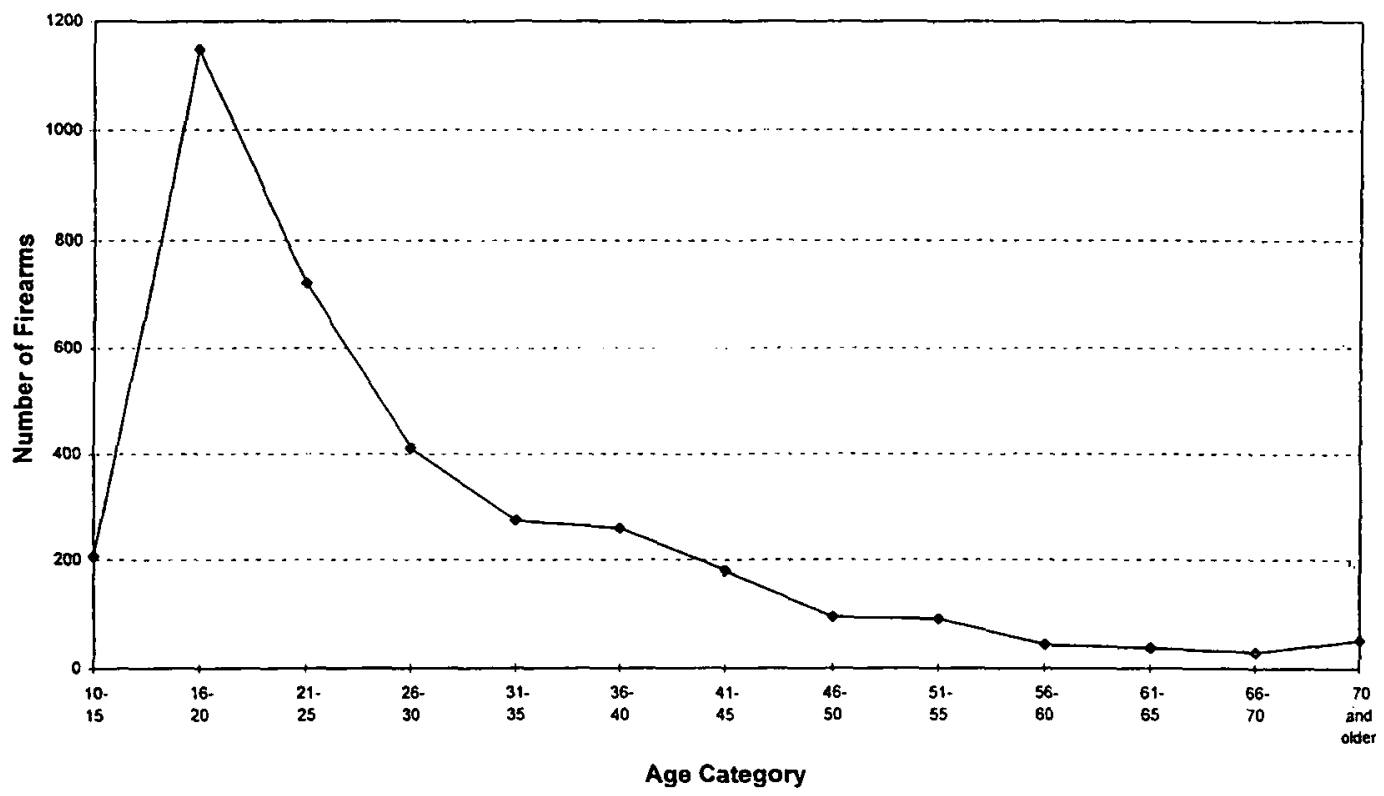

FIGURE 7

Time From First Retail SALE TO ReCOVERY By TyPE OF FIREARM, TRACEABle FIREARMS, PERSONS 21 AND UNDER

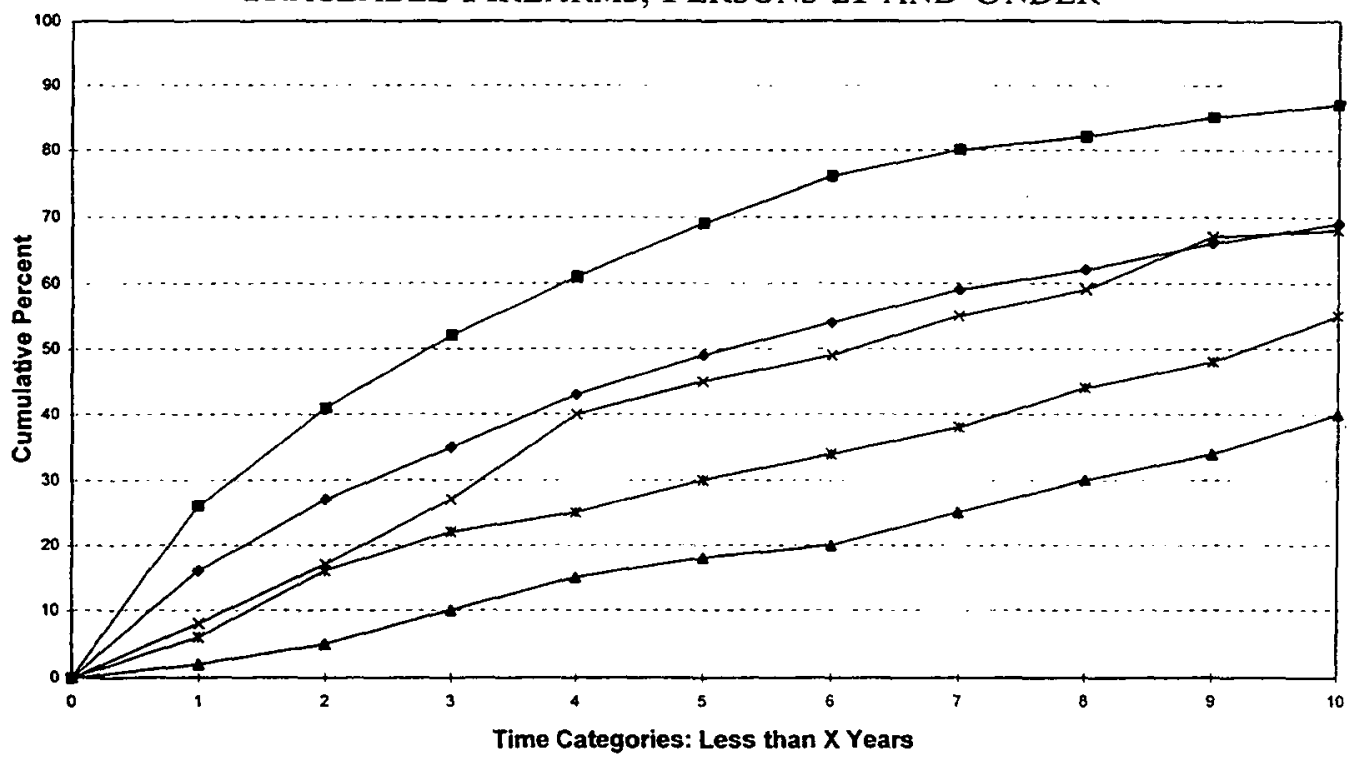

$\rightarrow$ All Traceable, $N=809 \rightarrow-$ Semiautomatics, $N=443 \rightarrow-$ Revolvers, $N=227 \rightarrow$ Shotguns, $N=75 \rightarrow-$ Rifles, $N=64$ 
FIGURE 8

Time From First Retail SALE to Recovery Traceable Semiautomatic Pistols Less Than 2 Years Old PERSONS 21 AND UNDER

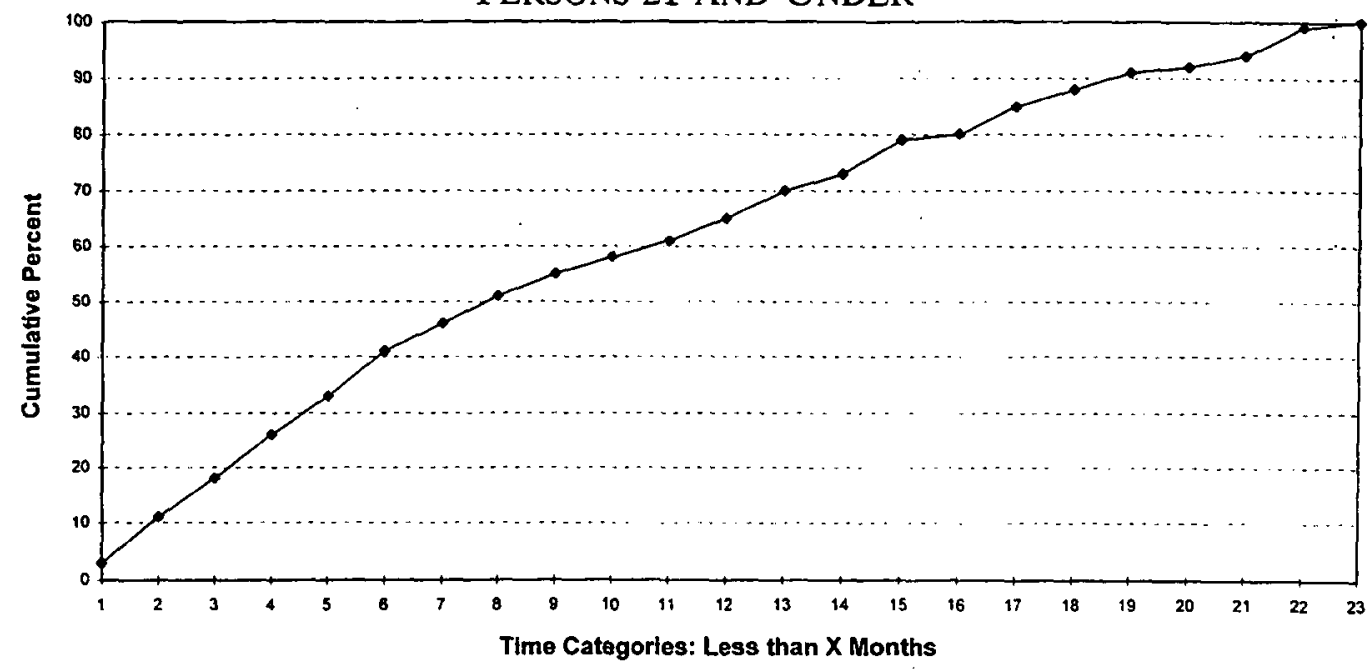

Semiautomatic Pistols, $N=180$

FIGURE 9

Time From First Retail Sale to Recovery Semiautomatic PISTOL BRANDS, TRACEABle FIREARMS, PERSONS 21 and UNDER

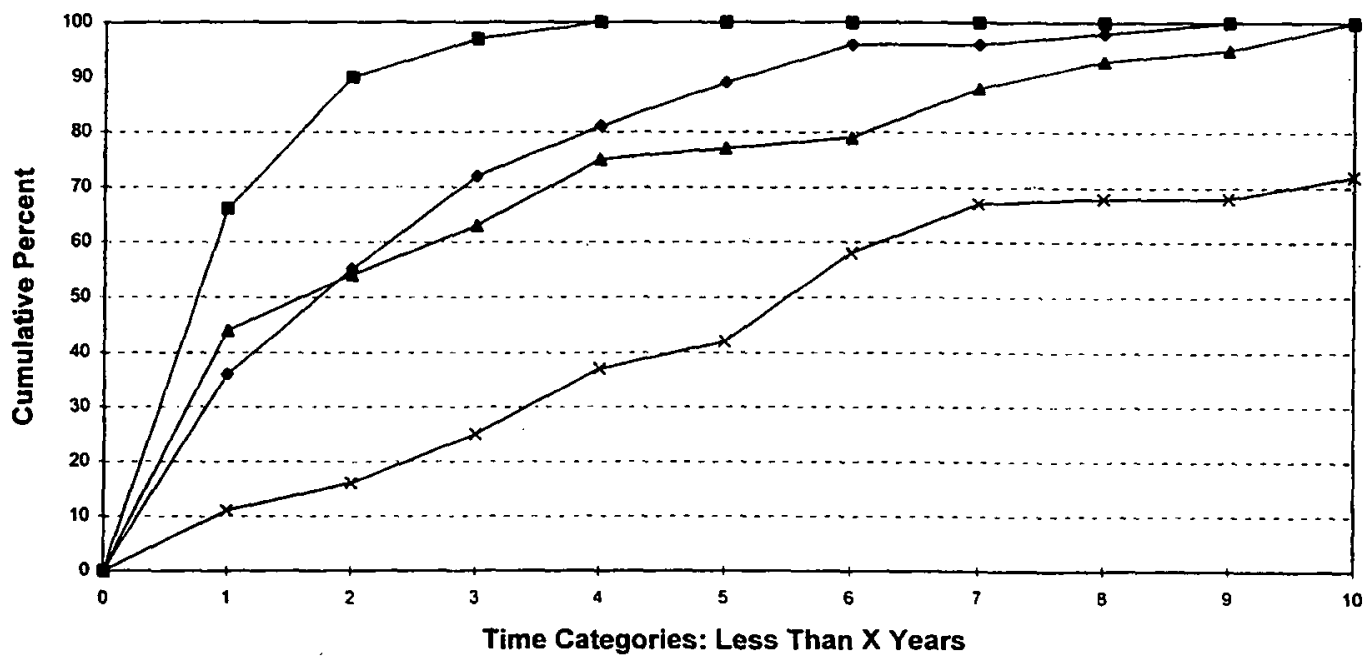


FIGURE 10

TIME From First RETAIL SALE TO RECOVERY

ADULT (30 AND OLDER) AND YOUTH (21 AND UNDER)

TRACEABLE CRIME AND POSSESSION FIREARMS

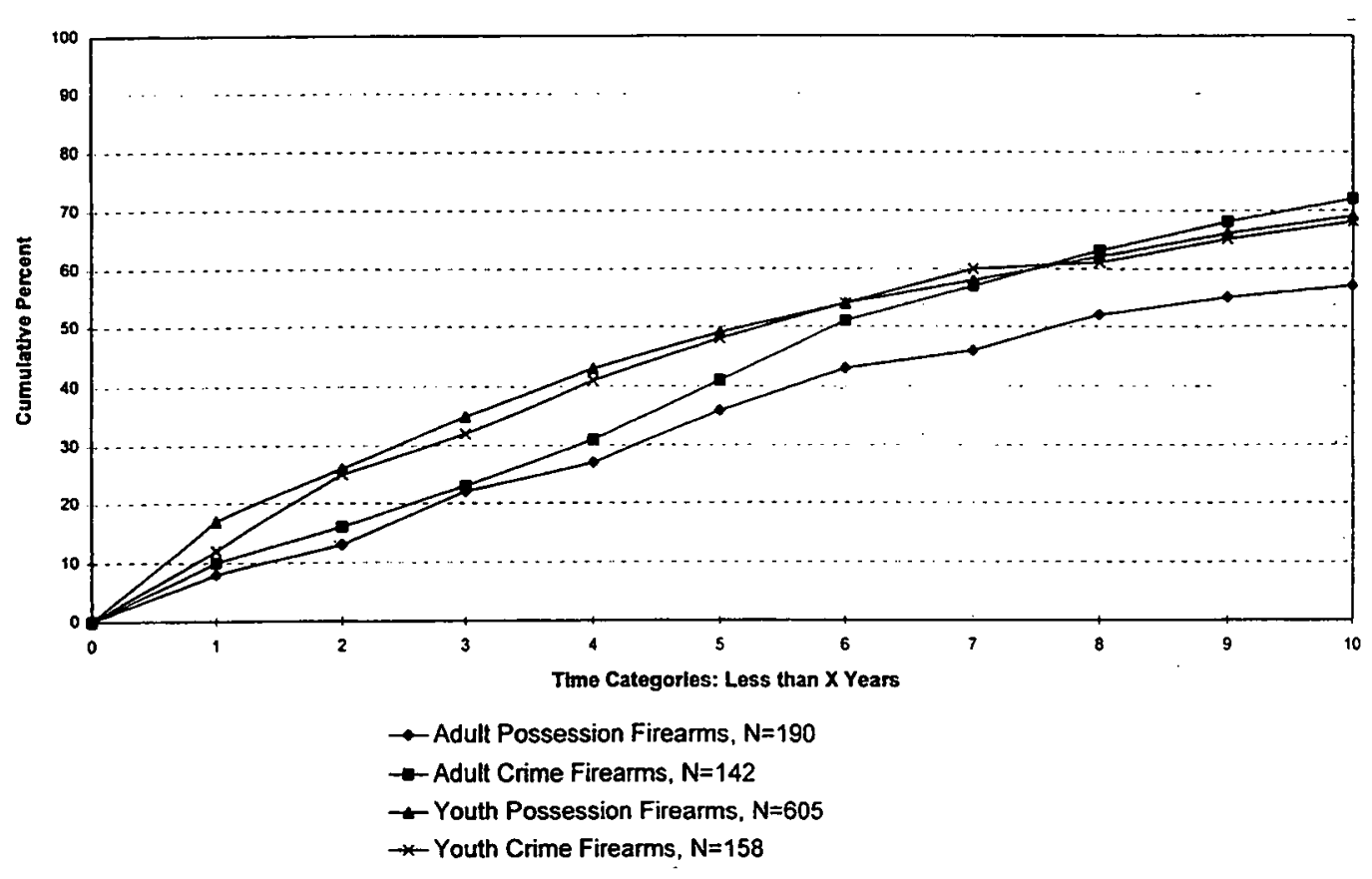




\section{TABLES $1-10$}

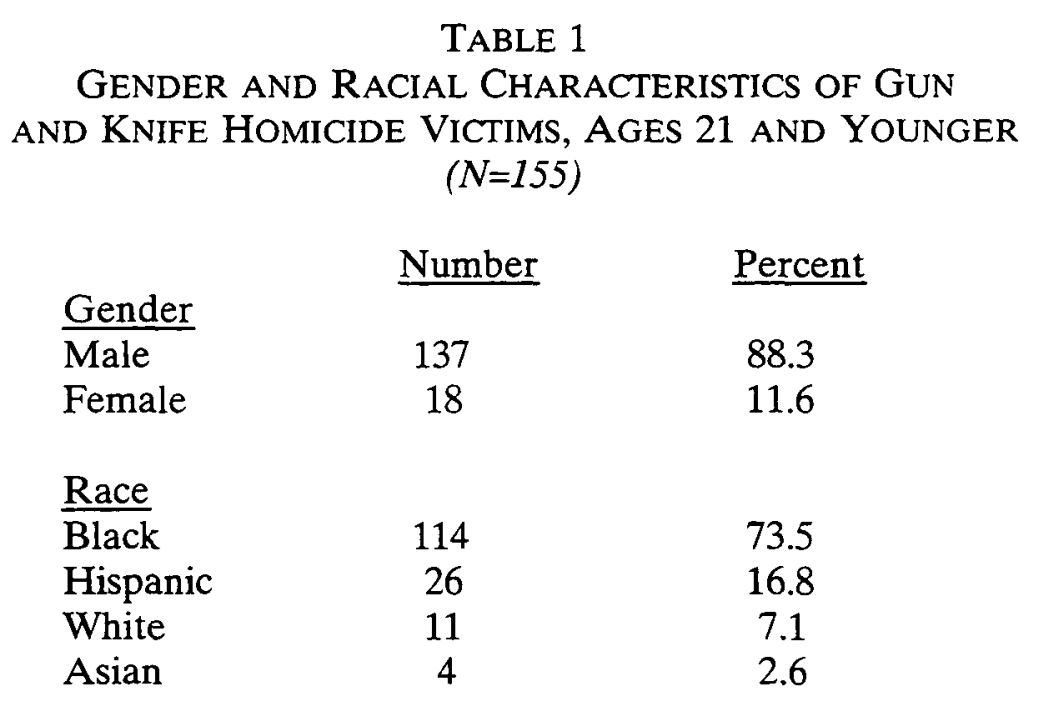

TABLE 2

OfFEnse Distribution of HOMICIDE Victims AND OFFENDERS

\begin{tabular}{|c|c|c|}
\hline Number of & Victims & Offenders \\
\hline Arraignments & $(N=155)$ & $(N=125)$ \\
\hline 0 & $24.5 \%$ & $23.2 \%$ \\
\hline 1 & $7.7 \%$ & $4.8 \%$ \\
\hline 2 & $5.2 \%$ & $5.6 \%$ \\
\hline 3 & $5.2 \%$ & $4.0 \%$ \\
\hline 4 & $4.5 \%$ & $8.0 \%$ \\
\hline 5 & $5.2 \%$ & $6.4 \%$ \\
\hline 6 & $6.5 \%$ & $8.0 \%$ \\
\hline 7 & $4.5 \%$ & $4.0 \%$ \\
\hline 8 & $1.3 \%$ & $3.2 \%$ \\
\hline 9 & $1.9 \%$ & $1.6 \%$ \\
\hline 10 or more & $33.5 \%$ & $31.2 \%$ \\
\hline
\end{tabular}




\section{TABLE 3}

DisTRIBUTION OF ESTIMATED GANG SIZE

CITY OF BOSTON

\begin{tabular}{|c|c|c|}
\hline Range & Number & Percent \\
\hline Less than 10 & 11 & 18.0 \\
\hline $10-19$ & 21 & 34.4 \\
\hline $20-29$ & 7 & 11.5 \\
\hline $30-39$ & 8 & 13.1 \\
\hline $40-49$ & 1 & 1.6 \\
\hline $50-59$ & 2 & 3.3 \\
\hline $60-69$ & 2 & 3.3 \\
\hline $70-79$ & 0 & 0.0 \\
\hline $80-89$ & 0 & 0.0 \\
\hline $90-99$ & 1 & 1.6 \\
\hline More than 100 & 1 & 1.6 \\
\hline Unknown & 7 & 11.5 \\
\hline
\end{tabular}

Source: David Kennedy, Anthony Braga, \& Anne Piehl, The (Un)known Universe: Mapping Gangs and Gang Violence in Boston, in CRIME MAPPING AND CRIME PREVENTION (David Weisburd \& J. Thomas McEwen eds., forthcoming).

TABLE 4

DisTRIBUTION OF SUBSTANTIVE CRIME CHARgES ASSOCIATED WITH RECOVERED GUNS

SUSPECTS AGES 21 AND YOUNGER

$$
(N=269)
$$

Crime

Assault

Assaulty \& Battery

with a Deadly Weapon

Homicide

Armed Robbery

Shootings/Shots Fired

Search Warrants

Discharge with Intent

$$
\text { to Injure }
$$

Accidental Discharge

Carjacking

Attempted Homicide $\underline{\text { Number }} \quad \underline{\text { Percent }}$

$115 \quad 42.7$

$44 \quad 16.4$

$44 \quad 16.4$

$42 \quad 15.6$

$8 \quad 2.9$

$7 \quad 2.6$

$4 \quad 1.5$

$2 \quad 0.7$

$2 \quad 0.7$

$1 \quad 0.4$ 
TABLE 5

FIREARMS RECOVERED FROM SUSPECTS 21 AND UNDER

RESULTS OF BATF TRACE

$(N=1,550)$

\begin{tabular}{|c|c|c|}
\hline Result & Number & $\underline{\text { Percent }}$ \\
\hline Traced to Purchaser & 443 & 28.6 \\
\hline Obliterated Serial Numbers & 305 & 19.7 \\
\hline Traced to Dealer & 223 & 14.4 \\
\hline Unable to Trace* & 196 & 12.6 \\
\hline Too Old to Trace** & 142 & 9.2 \\
\hline No Record with Dealer & 87 & 5.6 \\
\hline No Serial Number & 68 & 4.4 \\
\hline Traced to Police Department & 21 & 1.4 \\
\hline Out of Business Records & 20 & 1.3 \\
\hline Reported Stolen from Dealer & & \\
\hline $\begin{array}{l}\text { or Purchaser } \\
\text { Trace by Other Law Enforce- } \\
\text { ment Agency (ongoing or } \\
\text { previous investigation }\end{array}$ & 18 & 1.2 \\
\hline on firearm) & 9 & 0.6 \\
\hline Trace in Progress & 8 & 0.5 \\
\hline Traced to Foreign Country & 2 & 0.1 \\
\hline Trace Resubmitted to BATF & & \\
\hline National Trace Center & 1 & 0.1 \\
\hline
\end{tabular}

- "Unable to trace" is a BATF category used when (1) BATF is unable to locate an importer, an FFL, or a manufacturer, (2) when trace requests list improper serial numbers or models; or (3) when the firearm was manufactured prior to 1985 (these firearms were not traced after June 1994) or prior to 1990 (not traced after March 1995).

“ "Too old to trace" is a BATF category reserved for pre-1968 firearms. "No serial number" generally, but not invariably, indicated pre-1968 manufacture. Exceptions would include certain post-1968 foreign firearms subsequently brought into the United States, post-1968 domestic firearms improperly manufactured without serial numbers, and police department coding errors on trace requests, particularly with regard to obliterated or difficult-to-locate serial numbers. 


\begin{tabular}{lcc}
\multicolumn{3}{c}{ TABLE 6} \\
\multicolumn{1}{c}{ TyPe OF FIREARM, SUSPECTS 21 AND UNDER } \\
& $(N=1,550)$ & \\
Type & Number & Percent \\
\hline Semiautomatic Pistol & 807 & 52.1 \\
Revolver & 465 & 30.0 \\
Rifle & 132 & 8.5 \\
Shotgun & 146 & 9.4
\end{tabular}

TABLE 7

CALIBER OR GaUge OF FIREARMS RECOVERED FROM SUSPECTS 21 AND UNDER

\begin{tabular}{|c|c|c|c|c|}
\hline \multirow[b]{2}{*}{ Caliber/Gauge } & \multicolumn{2}{|c|}{$\frac{\text { All Firearms }}{(N=1,550)}$} & \multicolumn{2}{|c|}{$\frac{\text { Firearms Less than } 2 \text { Years Old }}{(N=215)}$} \\
\hline & $\underline{N}$ & Percent & $\mathrm{N}$ & Percent \\
\hline .22 & 276 & 17.8 & 19 & 8.8 \\
\hline .25 & 227 & 14.6 & 39 & 18.1 \\
\hline $9 \mathrm{~mm}$ & 215 & 13.9 & 58 & 27.0 \\
\hline .38 & 198 & 12.8 & 4 & 1.9 \\
\hline .380 & 180 & 11.6 & 52 & 24.2 \\
\hline .32 & 133 & 8.6 & 11 & 5.1 \\
\hline 12 gauge & 102 & 6.6 & 12 & 5.6 \\
\hline .357 & 73 & 4.7 & 3 & 1.4 \\
\hline .45 & 52 & 3.4 & 6 & 2.8 \\
\hline .30 & 23 & 1.5 & 0 & 0.0 \\
\hline 20 gauge & 19 & 1.2 & 1 & 0.5 \\
\hline .44 & 15 & 1.0 & 2 & 1.0 \\
\hline .40 & 6 & 0.4 & 5 & 2.3 \\
\hline All Other Calibers & 31 & 2.0 & 3 & 1.4 \\
\hline
\end{tabular}


TABLE 8

TOP FIVE BRANDS OF SEMIAUTOMATIC PISTOLS

\begin{tabular}{lcc}
\hline Brand & Number & Percent \\
\hline Raven & 90 & 11.2 \\
Davis & 89 & 1.0 \\
Bryco/Jennings & 58 & 7.2 \\
Lorcin & 53 & 6.6 \\
Colt & 39 & 4.8 \\
\hline
\end{tabular}

Table 9

SOURCE OF TRACEABLE FIREARMS RECOVERED FROM SUSPECTS 21 AND UNDER

\begin{tabular}{lcccc}
\hline & $\begin{array}{c}\text { All Traceable } \\
(N=809)\end{array}$ & $\begin{array}{c}\text { New Firearms* } \\
(N=215)\end{array}$ & $\begin{array}{c}\text { Possession } \\
(N=605)\end{array}$ & $\begin{array}{c}\text { Substantive Crime } \\
(N=158)\end{array}$ \\
\hline Source State & & & & \\
Massachusetts & $34.0 \%$ & $26.5 \%$ & $30.7 \%$ & $41.1 \%$ \\
Southern States & $31.5 \%$ & $38.6 \%$ & $33.9 \%$ & $28.5 \%$ \\
Other States & $34.5 \%$ & $34.9 \%$ & $35.4 \%$ & $30.4 \%$ \\
\hline
\end{tabular}

* "New firearms" are firearms recovered less than two years after first retail sale. 
TABLE 10

Firearm Characteristics of Possession and Substantive Crime Firearms
Youth (21 and Under) and Adult (30 and Older)

\begin{tabular}{|c|c|c|c|c|}
\hline & \multicolumn{2}{|c|}{ Youth } & \multicolumn{2}{|c|}{ Adult } \\
\hline & $\begin{array}{l}\text { Possession } \\
\mathrm{N}=1186\end{array}$ & $\begin{array}{l}\text { Substantive Crime } \\
\quad N=269\end{array}$ & $\begin{array}{l}\text { Possession } \\
N=462\end{array}$ & $\begin{array}{c}\text { Substantive Crime } \\
\qquad N=224\end{array}$ \\
\hline Recoveries $^{1}$ & $81.5 \%$ & $18.5 \%$ & $67.3 \%$ & $32.7 \%$ \\
\hline $\begin{array}{l}\text { Semiautomatic } \\
\text { Long gun }{ }^{2}\end{array}$ & $\begin{array}{l}53.2 \% \\
15.0 \%\end{array}$ & $\begin{array}{l}52.0 \% \\
23.1 \%\end{array}$ & $\begin{array}{l}41.6 \% \\
27.3 \%\end{array}$ & $\begin{array}{l}33.5 \% \\
39.1 \%\end{array}$ \\
\hline Obliterated & $21.8 \%$ & $13.4 \%$ & $9.5 \%$ & $2.7 \%$ \\
\hline $\begin{array}{l}\text { Source State } \\
\text { Massachusetts } \\
\text { Southern states }\end{array}$ & $\begin{array}{l}30.7 \% \\
33.9 \%\end{array}$ & $\begin{array}{l}41.4 \% \\
28.5 \%\end{array}$ & $\begin{array}{l}35.2 \% \\
27.6 \%\end{array}$ & $\begin{array}{l}65.5 \% \\
12.7 \%\end{array}$ \\
\hline
\end{tabular}

${ }^{1}$ Recovery percents were calculated based on the pools of possession and substantive crime guns; the 95 youth guns and 446 adult guns recovered under other circumstances, such as found guns or safekeeping were excluded from these analyses.

2 Shotguns and rifles.

${ }^{3}$ The percentage of guns originating from Massachusetts or Southern states was calculated from traceable firearms; the traceable firearm Ns were as follows: youth possession firearms, $N=605$; youth substantive crime firearms, $\mathrm{N}=158$; adult possession firearms, $\mathrm{N}=253$; and adult substantive crime firearms, $\mathrm{N}=142$. 